University of Montana

ScholarWorks at University of Montana

\title{
If Skilling Can't Get A Change Of Venue, Who Can? Salvaging Common Law Implied Bias Principles from the Wreckage of the Constitutional Pretrial Publicity Standard
}

Jordan Gross

Alexander Blewett III School of Law at the University of Montana, jordan.gross@umontana.edu

Follow this and additional works at: https://scholarworks.umt.edu/faculty_lawreviews

Part of the Constitutional Law Commons

Let us know how access to this document benefits you.

\section{Recommended Citation}

Gross, Jordan, "If Skilling Can't Get A Change Of Venue, Who Can? Salvaging Common Law Implied Bias Principles from the Wreckage of the Constitutional Pretrial Publicity Standard" (2013). Faculty Law Review Articles. 104.

https://scholarworks.umt.edu/faculty_lawreviews/104

This Article is brought to you for free and open access by the Faculty Publications at ScholarWorks at University of Montana. It has been accepted for inclusion in Faculty Law Review Articles by an authorized administrator of ScholarWorks at University of Montana. For more information, please contact scholarworks@mso.umt.edu. 


\title{
IF SKILLING CAN'T GET A CHANGE OF VENUE, WHO CAN? SALVAGING COMMON LAW IMPLIED BIAS PRINCIPLES FROM THE WRECKAGE OF THE CONSTITUTIONAL PRETRIAL PUBLICITY STANDARD
}

\author{
Jordan Gross ${ }^{*}$
}

\begin{abstract}
Fifty years ago, the United States Supreme Court issued three landmark decisions recognizing local pretrial publicity and community hostility in a charging venue as extraneous forces that can impact jurors' ability to be constitutionally impartial. It later held that local prejudice can be so incompatible with a defendant's right to an impartial jury that a trial in that community violates due process and may require a change in venue. Paradoxically, successful venue challenges under this federal constitutional pretrial publicity standard have become increasingly rare even as the volume, sensationalism, and pervasiveness of media coverage of criminal trials have increased with near-universal television and Internet access in the United States. This Article tracks the Supreme Court's effort, and ultimate failure, to develop a coherent jurisprudence addressing the effects of pretrial publicity on juror impartiality in a media-saturated society. This failure has culminated in a systematic dismantling of the pretrial publicity standard. The result is a fragmented and highly malleable change-ofvenue jurisprudence under a "totality of the circumstances" test that rarely results in a change of venue, even in the most notorious and highly publicized of contemporary cases, like the prosecution of Jeffrey Skilling for his Enron-related offenses.

A few courts and commentators have argued that the extent of the harm caused by a crime should be an additional factor (along with pretrial publicity) that informs a federal trial court's change-of-venue analysis under Federal Rule of Criminal Procedure 21 and/or the constitutional totality of the circumstances inquiry. This Article agrees that the pretrial publicity standard does not adequately address the effect of widespread community harm on juror bias. However, it disagrees with the assumption that the Rule 21 inquiry is coextensive with the constitutional inquiry, and that grafting one more normative factor onto an already highly subjective multifactor test will provide any more protection to the impartial jury rights of high-profile defendants or result in a more coherent change-of-venue jurisprudence. Rather, this Article argues that a deeper problem with the current change-of-venue standard is that it has displaced common law principles of jury bias that should lead to a different analysis in cases involving contemporary crimes-crimes that bear little resemblance
\end{abstract}

* Assistant Professor, University of Montana School of Law. 
to the cases that gave rise to the constitutional change-of-venue standard. These crimes are specifically those that cause or threaten catastrophic harm in the charging venue and create a large victim class in the community of people with a direct interestpecuniary, emotional, or otherwise-in the outcome of the case. In those cases, this Article argues, a natural extension of the common law doctrine of implied juror bias to the community requires a conclusive presumption of community-wide bias warranting a change of venue.

Section II of this Article discusses common law principles of jury bias. Section III tracks the evolution of the Court's pretrial publicity standard, with a particular focus on the impartial jury/free press concerns that initially drove this jurisprudence, up to its most recent consideration of this area of law in United States v. Skilling. Section IV explains why common law principles of implied bias warrant recognizing a conclusive presumption of community-wide bias in a discrete class of modern high-impact cases to fully protect the Sixth Amendment constitutional impartial jury guarantee.

\section{TABLE OF CONTENTS}

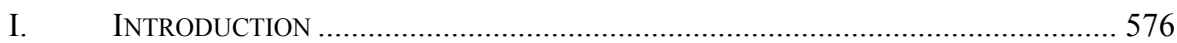

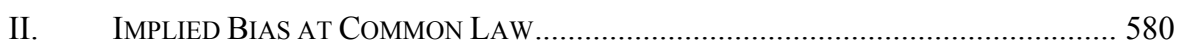

III. IMPLIED BiAs IN THE Age of MASS MEDiA-TRAJECTORY OF THE PRETRIAL PUBLICITY STANDARD .......................................................... 582

A. The "Vexing Subject" of Trial by Newspaper ...................................... 582

B. Sounding the Alarm-Irvin, Rideau, Sheppard .................................. 585

C. Retreat and Retrenchment-Murphy, Patton, Mu'min ......................... 592

D. Taking Stock — an Unpredictable and Uneven Justice..........................60 600

E. Skilling and What it Left Unanswered ............................................. 610

IV. THE COMMON LAW CASE For RECOGNIZING IMPLIED COMMUNiTy Bias IN CASES INVOLVING CATASTROPHIC LoCAL HARM ........................................... 615

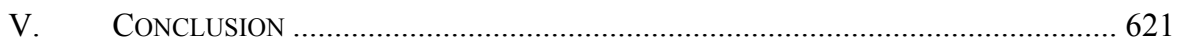

"There must be some way out of here," said the joker to the thief, "There's too much confusion, I can't get no relief."1

\section{INTRODUCTION}

The Constitution requires the government to try criminal cases before an impartial jury of the state and district where the crime was committed. ${ }^{2}$ The Constitution does not

1. Bob Dylan, All Along the Watchtower, on John WeSLEy HARDING (Columbia Records 1967).

2. The Sixth Amendment provides that a criminal defendant is entitled to a trial before an "impartial jury of the State and district wherein the crime shall have been committed." U.S. CONST. amend. VI. Article III, Section 2 of the Constitution requires that criminal trials "shall be held in the State where the said Crimes shall have been committed; but when not committed within any State, the Trial shall be at such Place or Places as the Congress may by Law have directed." U.S. CONST. art. III, § 2, cl. 3. 
hierarchize between the guarantees of an impartial jury and the location of criminal trials. On the contrary, the constitutional jury trial framework rests on the assumption that the place of trial and the impartial jury guarantees are compatible; that is, that an impartial jury can be drawn from the community where the crime was committed even though jurors in the charging venue may have personal knowledge about the crime or individuals involved. ${ }^{3}$ Local knowledge and impartiality, in the founders' view, were not mutually exclusive.

This constitutional understanding of juror impartiality has undergone a complete transformation in modern times. At the founding, a juror would be expected to have some familiarity with a case; today jurors can be excluded precisely because they know about a case. ${ }^{4}$ At the founding, a juror would be expected to rely on firsthand knowledge of the defendant, victim, witnesses, and the community in which the crime was committed as context for rendering a judgment; today, an impartial juror is one who swears to base his or her verdict strictly on evidence adduced at trial. ${ }^{5}$ This shift in the constitutional definition of impartiality can be traced to courts' early encounters with the phenomenon of high-profile criminal prosecutions accompanied by significant publicity in the charging venue. ${ }^{6}$ In this context, courts made a judgment that this secondhand information, unlike jurors' firsthand knowledge, posed a risk of influencing the decision-making process in a way that is fundamentally incompatible with a constitutionally fair trial. ${ }^{7}$ And courts made a legal judgment that, as between the constitutional local trial and impartial jury guarantees, the latter would trump the former. ${ }^{8}$

The ascent of television as a major source of news information for Americans has allowed faster and wider dissemination of information about criminal trials and presented a new challenge for courts seating jurors in high-profile cases. As television publicity emerged, courts addressed this challenge by relying on traditional procedural tools and remedies, such as targeted voir dire, instructions to the jury, and changes of venue. $^{9}$ The constitutional adequacy or necessity of these remedies, however, was unresolved until the 1960s, when the Supreme Court overturned three state convictions on postconviction review based on pretrial publicity, community hostility, and media

3. The Sixth Amendment "was drafted at a time when the interests of the defendant and those of the community in which the crime took place seemed to be coincident. Given the limited mobility of the time, the defendant's residence and the community in which the crime took place were frequently one and the same." NANCY GERTNER \& JUDITH H. MizNER, THE LAW OF JURIES 181 (5th ed. 2011).

4. See infra Section II for an analysis of how jurors' knowledge affects their selection to a jury.

5. See infra notes 29-33 and accompanying text for a discussion of the qualities of an impartial juror today.

6. See infra Parts III.A and III.B for a examples of cases involving a considerable amount of media attention.

7. See infra notes 34-41 and accompanying text for a discussion of the courts' early encounters with juries and fair trials.

8. See infra Part III.A for an analysis of the first cases the Court decided regarding change of venue due to jurors' impartiality problems.

9. See, e.g., Delaney v. United States, 199 F.2d 107, 112-13 (1st Cir. 1952) (suggesting several procedural remedies to avoid media-run trials). 
interference with court proceedings. ${ }^{10}$ In those cases, the Court held for the first time that, as a matter of due process, trial courts may be required to exclude jurors who have been exposed to prejudicial influences in the charging venue because exposure to those types of outside influences may compromise a juror's ability to be impartial under the modern definition of juror impartiality; that is, outside influences may undermine a juror's ability to base a verdict solely on the evidence at trial. In one of these early cases, the Court further held that these types of influences may be so pernicious in the charging venue wherein a presumption of community bias will arise that cannot be overcome by either careful questioning in voir dire or instructions to the jury. ${ }^{11}$ Significantly, and not without dissent, the Court later established that in some cases, a change of venue may be the only constitutionally adequate procedural remedy for this type of jury bias. ${ }^{12}$

Paradoxically, successful venue challenges under this federal constitutional pretrial publicity standard have become increasingly rare, even as the volume, sensationalism, and pervasiveness of media coverage of criminal trials have increased exponentially with nearly universal access to information through television and the Internet in the United States. ${ }^{13}$ Thus, under circumstances that should lead to more changes of venue based on pretrial publicity, there have actually been fewer. This is the result not of a reasoned and transparent judgment by the Supreme Court that, after all, pretrial publicity does not threaten the constitutional impartial jury right. Rather, within a short time of establishing the constitutional pretrial publicity standard, the Court began backpedaling from its potentially broad implications. ${ }^{14}$ A careful reading of the Court's precedents in this area reveals nothing short of a judicial dismantling of the pretrial publicity standard to virtually eliminate the possibility of successful venue challenges without ever explicitly overruling the precedents that established the standard. Unfortunately, the Court's approach to its impartial jury/free press dilemma has resulted in a confused and fragmented change-of-venue jurisprudence that offers little more than an illusion of constitutional protection to criminal defendants.

The Supreme Court agreed to hear its first change-of-venue case in almost two decades when it took up Jeffrey Skilling's contention that he should not have been tried for his Enron-related crimes in Houston in light of the extraordinary level of community hostility and prejudicial pretrial publicity in that venue. ${ }^{15}$ The Court's

10. See infra Part III.B for a discussion of Irvin v. Dowd, Rideau v. Louisiana, and Sheppard v. Maxwell.

11. See Rideau v. Louisiana, 373 U.S. 723, 726-27 (1963) (holding that even with a particularized voir dire, change of venue was appropriate to further impartiality).

12. See Groppi v. Wisconsin, 400 U.S. 505, 510-11 (1971) (holding that in some cases, a change of venue may be the only constitutionally adequate remedy for prejudicial pretrial publicity). See infra note 128 for a further discussion of Groppi v. Wisconsin.

13. See infra notes 231-32 and accompanying text for a discussion of the recent cases that have had successful venue challenges.

14. See infra Part III.C for an analysis of Supreme Court opinions that narrowed the pretrial publicity standard.

15. United States v. Skilling, 554 F.3d 529, 557-65 (5th Cir. 2009) (holding that the district court's voir dire mitigated any effects of community prejudice), cert. granted, $130 \mathrm{~S}$. Ct. 393 (2009). 
decision to consider Skilling's venue challenge prompted some observers to anticipate long-overdue guidance in a neglected and disjointed area of federal constitutional law. ${ }^{16}$ The Court's 2010 decision in Skilling v. United States, ${ }^{17}$ however, did not alter, refine, or change the law in any significant respect, or provide any new direction to lower courts and practitioners. ${ }^{18}$ Instead, a divided Court bickered about the proper interpretation and weight to give the evidence of jury bias in Skilling's case, mirroring the analytic inconsistencies that have come to characterize lower court decisions in this area and leaving several important questions of law unresolved. The most that can be said of Skilling's impact on change-of-venue jurisprudence is that, to the extent there was any lingering doubt on this score, the Court has conclusively limited its original change-of-venue precedents strictly to their facts and confirmed that trial courts' jury bias decisions will remain virtually unreviewable.

The Court's retreat from the constitutional pretrial publicity standard, this Article argues, is complete. And this retreat in the face of contemporary jurors' increased exposure to information about criminal cases is nothing less than a tacit acknowledgement that the realities of conducting criminal trials in a media-saturated society have outstripped the Court's willingness to require trial courts to incur the expense and inconvenience that more frequent changes in venue would require. In doing so, the Court has endorsed a constitutional pretrial publicity standard that only requires a change of venue to the extent a particular trial court is inclined to grant it. ${ }^{19}$ The upshot is that the constitutional definition of jury impartiality has undergone yet another transformation, but this time by stealth - it is safe to say that a constitutionally impartial jury in a contemporary high-profile case is now one that a given trial court subjectively believes to be impartial. This is a definition, obviously, that will differ among judges and that, unwittingly or not, may be influenced by an individual judge's tolerance for the judicial efficiency and economy costs that a change in venue presents.

This approach to evaluating jury bias is not only unreliable and unpredictable, its implementation obscures legitimate differences among high-profile cases. Such differences are grounded in common law principles regarding juror bias, separate and apart from the pretrial publicity concerns. Specifically, the common law doctrine of "principal challenge" recognizes a conclusive presumption of bias where a juror has a relationship to a party, witness, or attorney in the case, or a vested interest in its outcome, and it requires exclusion of that juror without any showing of actual prejudice. ${ }^{20}$ Regardless of the Court's inability (or unwillingness) to reconcile early

16. See, e.g., William H. Farmer, Presumed Prejudiced, but Fair?, 63 Vand. L. Rev. En Banc 5, 9 (2010). See infra Part III.E for a discussion of United States v. Skilling and the legal community's reaction to the Court's grant of certiorari.

17. 130 S. Ct. 2896 (2010).

18. See infra Part III.E for a discussion of Skilling v. United States and an analysis of the Supreme Court's decision.

19. See infra note 234 and accompanying text for a discussion of the great deference given to trial courts.

20. United States v. Wood, 299 U.S. 123, 135 (1936). See infra Section II for a discussion of implied bias at common law. 
concerns about the impact of media coverage on defendants' fair trial guarantees, this Article argues that a natural extension of the common law prompts a conclusive presumption precluding trial in the constitutionally mandated regime. Specifically, the traditional common law doctrine of implied bias demands that courts recognize a conclusive presumption of community-wide bias that precludes trial in the venue where the underlying crimes occurred. This limited class includes crimes that cause or threaten catastrophic harm unique to the charging venue, such as terrorist, environmental, and major financial offenses that create a large victim class in the charging venue with a direct interest - pecuniary, emotional, or otherwise - in the outcome of the case.

Section II of this Article discusses common law principles of jury bias. Section III tracks the evolution of the Court's pretrial publicity standard, with a particular focus on the impartial jury/free press concerns that initially drove this jurisprudence, culminating with the Court's most recent incursion into this area of law in Skilling. Section IV argues that, separate and apart from the pretrial publicity standard, common law principles require recognizing a presumption of community-wide bias in a discrete class of modern high-impact cases to fully protect the Sixth Amendment impartial jury guarantee.

\section{IMPLIED BiAS AT COMMON LAW}

At common law, a party could bring a challenge to the array of the jury (i.e., the entire jury as constituted) or challenge to the polls (i.e., to individual jurors). ${ }^{21} \mathrm{~A}$ challenge to individual jurors could be based, among other things, on a lack of qualification, suspicion of bias or partiality, or conviction of an infamous offense. ${ }^{22} \mathrm{~A}$ challenge to the poll could take the form of a "principal challenge" or a "challenge to the favor." 23 A principal challenge arises "when the connection between the prospective juror and either party" is so close that bias is conclusively presumed, ${ }^{24}$ such that the matter presents "prima facie evident marks of suspicion either of malice or

21. Wood, 299 U.S. at 134-35.

22. 1 Robert S. Hunter, Federal Trial Handbook: Criminal $\S 16: 1$ (4th ed. 2012).

23. McCarten v. Connecticut Co., 131 A. 505, 508 (Conn. 1925). The Supreme Court of Errors of Connecticut further explained:

At common law, a challenge to the polls, as distinguished from a challenge to the array, would lie for want of qualifications, as for alienage or infancy, or a prior conviction for certain infamous crimes, as well as for bias or prejudice. A challenge for this cause could be either a principal challenge or a challenge to the favor, as it was called. Of the former were relationship to either party to the suit, a former service as arbitrator on either side, an interest in the outcome of the suit, either personal or as a member of a corporation, or the relation of master or servant, steward, attorney, landlord or tenant to either party, or that the prospective juror has conversed with either party upon the merits of the case, or has formed or expressed an opinion on the question at issue. Such facts being proved, the disqualification was conclusively presumed. It was a legal conclusion, and it could not be rebutted.

Id.

24. HUNTER, supra note $22, \S 15.21$. 
favour" based on a juror's relationship to the case, including:

that a juror is of kin to either party within the ninth degree; that he has been arbitrator on either side; that he has an interest in the cause; that there is an action depending between him and the party; that he has taken money for his verdict; that he has formerly been a juror in the same cause; that he is the party's master, servant, counsellor, steward, or attorney, or of the same society or corporation with him: all these are principal causes of challenge; which, if true, cannot be overruled. ${ }^{25}$

These types of relationships are "held to import absolute bias or favor and require the disqualification of the juror as a matter of law." ${ }^{26}$ In contrast with a principal challenge, a challenge to the favor is based on actual bias in favor of a party. ${ }^{27} \mathrm{~A}$ challenge to the favor is based on the facts and circumstances of the case and does not create a conclusive presumption. ${ }^{28}$

The Sixth Amendment reflects the common law impartial jury right in the Constitution, but it also created a local jury requirement. Thus, the Sixth Amendment does not simply require an impartial jury; rather, it specifies that the impartial jury be of the state and district where the crime was committed. ${ }^{29}$ The Sixth Amendment "prescribes no specific tests" for evaluating bias. ${ }^{30}$ The history of the Sixth Amendment makes clear, however, that the local trial requirement reflects a jury model in which "knowing about a case and about the community asked to judge it qualified rather than disqualied [sic] a person for jury duty." 31 In contrast, modern constitutional law embraces a notion "that distance puts justice in perspective" and that the definitions of impartial jurors and knowledgeable jurors are mutually exclusive. ${ }^{32}$ This transition away from the notion that a local jury is especially qualified to judge a case precisely because it is drawn from the community most familiar with it is a defining feature of modern courts' definition of an impartial jury. ${ }^{33}$

A turning point in the evolution of the modern construct of an impartial jury was the highly publicized and highly politicized 1807 trial of Aaron Burr for treason and

25. Wood, 299 U.S. at 133 (quoting 3 William BlacKSTONE, COMMENTARIES *363).

26. State v. Kokoszka, 193 A. 210, 211 (Conn. 1937).

27. HUNTER, supra note 22, § 20:22; see also Kokoszka, 193 A. at 211 (describing a principal challenge as bias that is presumed to exist because of the relationship that a juror has with either party, which is irrebutable); BLACKSTONE, supra note 25 , at $* 363$ (describing that a principal challenge favor arises where the party has no principal challenge, but is able to show only some probable circumstances of suspicion).

28. See McCarten, 131 A. at 508 ("Challenges for favor were founded on probably circumstances of suspicion, as, for example, ... facts as would tend to show bias, but did not create a conclusive presumption of disqualification.").

29. U.S. CONST. amend. VI.

30. Wood, 299 U.S. at 133.

31. JefFrey Abramson, We, the Jury: The Jury System AND the IdEAl of Democracy 21 (2003); see also GERTNER \& MIZNER, supra note 3, at 181 (describing the constitutional requirement of a jury of the charging venue enacted as a reaction to the Crown's late 18th century practice of transporting colonists accused of crimes to other colonies or to England for trial).

32. ABRAMSON, supra note 31 , at 21 .

33. Id. at $36-38$. 
related crimes. ${ }^{34}$ At his trial, Burr argued that news coverage of his case had created such prejudice that jurors who admitted to reading and being influenced by those accounts had to be struck for bias because they had formed an opinion about the matters to be tried. ${ }^{35}$ At the time of Burr's trial, a potential juror would be removed for "favor" only if the juror had formed an opinion on the ultimate issue before the jurythe guilt or innocence of the defendant - or because the juror harbored ill will towards the defendant. ${ }^{36}$ There was no cause for favor simply because a juror was knowledgeable about the case or because he had formed an opinion on some aspect of the case based on this knowledge. ${ }^{37}$

Chief Justice John Marshall, sitting by designation as a circuit judge, agreed with Burr, interpreting the constitutional impartial jury guarantee to require disqualification of jurors who had expressed any opinion on "any fact conducive to the final decision of the case" (i.e., jurors who had prejudged any underlying aspect of the case bearing on guilt or innocence) ${ }^{38}$ Chief Justice Marshall, it should be noted, did not hold that all pretrial knowledge created bias. ${ }^{39}$ Rather, he carefully distinguished between opinions based on a juror's own personal knowledge and opinions based on reports and newspaper publications. ${ }^{40}$ Under this analytical framework, it was the juror who knew nothing of the case, yet prejudged it based on newspaper accounts, who "manifests a bias that completely disqualifies him[] from the functions of a juryman."41

\section{ImPlied Bias In the Age of Mass Media-Trajectory of the Pretrial PUBLICITY STANDARD}

\section{A. The "Vexing Subject" of Trial by Newspaper}

Following Burr, courts generally accepted the premise that publicity surrounding criminal trials has a potentially corrupting influence on juror impartiality. ${ }^{42}$ And courts,

34. See Alfredo Garcia, Clash of the Titans: The Difficult Reconciliation of a Fair Trial and a Free Press in Modern American Society, 32 Santa Clara L. Rev. 1107, 1109-10 (1992) (describing Chief Justice Marshall's struggles with selecting impartial jurors); Kevin E. Sralla, Note, The Search for Harmful Prejudice: An Analysis of People v. Budzyn and the Underlying Purpose of the Jury System, 46 WAYNE L. REV. 259, 266-67 (2000) (describing Burr's 1807 treason trial as one of the most "highly publicized trials in early American history" and noting that it gave rise to Marshall's "groundbreaking interpretation of the constitutional guarantee of an 'impartial' jury").

35. ABRAMSON, supra note 31 , at 41 .

36. Id.

37. Id. at $41-42$.

38. United States v. Burr, 25 F. Cas. 49, 51 (C.C.D. Va. 1807) (No. 14,692g).

39. Id. at $50-51$

40. Id. at 52 .

41. Id. at 77; see also ABRAMSON, supra note 31, at 43 ("In this way, the problem of pretrial knowledge became the problem of pretrial publicity.").

42. See Krogmann v. United States, 225 F.2d 220, 228 (6th Cir. 1955) (holding that newspaper articles actually read by jurors that convey highly prejudicial information not admissible or admitted at trial have long been recognized as constituting such essential unfairness as to justify the setting aside of the verdict and the 
including the Supreme Court, recognized that in some instances, a juror's exposure to news accounts might require setting aside a conviction. ${ }^{43}$ The Court, however, did not directly consider whether the impact of prejudicial pretrial publicity could require a change of venue to secure an impartial jury until $1961 .{ }^{44}$ When the Court did take up this question, lower courts had been struggling for some time to address the potential conflict between the impartial jury right and First Amendment press freedoms in an era of unprecedented and widespread dissemination of information about high-profile criminal prosecutions. ${ }^{45}$ Thus, by the mid-1900s, after courts had embraced the definition of an impartial juror as one untainted by external influences, ${ }^{46}$ they were confronted with an external influence of monumental and unanticipated proportionswidespread broadcasting of information about high-profile criminal cases.

Delaney v. United States, ${ }^{47}$ a closely watched and sensational criminal case decided almost a decade before the Supreme Court issued its first change-of-venue decision ${ }^{48}$ is illustrative of lower courts' efforts to shepherd the modern notion of juror impartiality through the free press/fair trial predicament exacerbated by the arrival of television and rapid nationwide coverage of sensational criminal trials. ${ }^{49}$ Delaney also offers a valuable contemporaneous account of lower courts' frustrations with this issue and their uncertainty about how to confront it. ${ }^{50}$ Denis Delaney was the Collector of Internal Revenue for the District of Massachusetts. ${ }^{51} \mathrm{~A}$ federal grand jury indicted him with receiving bribes and related offenses. ${ }^{52}$ Delaney's case generated widespread pretrial publicity, particularly in the Boston area. ${ }^{53}$ As Delaney's criminal case

granting of a new trial).

43. See Marshall v. United States, 360 U.S. 310, 312-13 (1959) (setting aside a federal conviction where the jurors were exposed through news accounts to information that was not admitted at trial and noting that prejudice from such material may be greater than when it is part of the prosecution's evidence).

44. See Irvin v. Dowd 366 U.S. 717, 726-28 (1961) (discussing jury bias and the need to impanel a jury that has not already decided the defendant's guilt).

45. Id.; see also United States ex rel. Brown v. Smith, 200 F. Supp. 885, 907 (D. Vt. 1962) (finding that the defendant was convicted by a juror lacking impartiality), rev'd, 306 F.2d 596 (2d Cir. 1962); United States ex rel. De Vita v. McCorkle, 133 F. Supp. 169, 176 (D. N.J. 1955) (finding that defendant had been convicted by an impartial jury), rev'd, 248 F.2d 1 (3d Cir. 1957).

46. See Patterson v. Colorado, 205 U.S. 454, 462 (1904) (explaining that jurors must reach their decisions based on the evidence and argument presented at trial "and not by any outside influence, whether of private talk or private print"); see also Coughlin v. People, 144 Ill. 140, 177 (1893) ("A juror should stand indifferent between the parties. No bias should influence his judgment, and swerve him from strict impartiality.” (quoting Ins. Co. v. Schueller, 60 Ill. 465, 472 (1871))).

47. 199 F.2d 107 (1st Cir. 1952).

48. See Delaney, 199 F.2d at 109, 113 (referring to the "widespread" publicity Delaney's suspension, removal, indictment, and arraignment, particularly in the Boston area, and the "widespread" publicity generated by the Congressional committee hearings into the Delaney allegations and the committee's role in the "massive pre-trial publicity, on a nationwide scale" that preceded Delaney's trial).

49. Id. at 113 .

50. Id. (citing several cases that addressed the prejudicial effect of publicity on litigants).

51. Id. at 109 .

52. Id.

53. Id. 
unfolded, a subcommittee of the House of Representatives - the King Committeeinformed Delaney that it intended to investigate his former office..$^{54}$ Over protests from Delaney's attorney and the Department of Justice, the King Committee took evidence and heard public testimony about corruption in Collector's Offices generally, and about the Boston office and Delaney in particular. ${ }^{55}$ In these hearings, the King Commission elicited information about matters for which Delaney had not been charged, and motion and sound recordings of the public hearings were created. ${ }^{56}$ The press in Boston, where Delaney was to be tried, covered the hearings extensively. ${ }^{57}$ Before trial, Delaney unsuccessfully moved for a continuance to allow the hostile environment surrounding the case to dissipate. ${ }^{58}$

The First Circuit vacated Delaney's conviction and remanded. ${ }^{59}$ It described the newspaper publicity surrounding the hearings and Delaney's indictment as "characterized by flamboyant, front-page headlines ... [and] stories emphasizing the more striking aspects of the testimony . . . . supplemented by radio and television exploitation of the same material. ${ }^{\prime 60}$ Noting the national reach of the publicity, it observed that it was "fair to say that, so far as the modern mass media of communication could accomplish it, the character of Delaney was pretty thoroughly blackened and discredited as the day approached for his judicial trial on narrowly specified charges." ${ }^{\prime 61}$ Delaney, the First Circuit held, should not have been forced to go to trial until the effects of the prejudice caused by the pretrial publicity had worn off enough to allow the trial to proceed "free of the enveloping hostile atmosphere and public preconception of guilt" present when Delaney went to trial. ${ }^{62}$ The First Circuit noted that the trial court attempted to minimize the effects of the prejudicial pretrial publicity by questioning and instructing the jury. ${ }^{63}$ But it dismissed these measures as inadequate, observing that the notion that such steps can overcome juror prejudice is known by all practicing lawyers "to be unmitigated fiction." 64 "One cannot assume," the First Circuit observed, "that the average juror is so endowed with a sense of detachment, so clear in his introspective perception of his own mental processes that he may confidently exclude even the unconscious influence of his preconceptions as to probable guilt, engendered by a pervasive pretrial publicity." ${ }^{65}$

The First Circuit's comments about the challenges faced by trial courts attempting to protect the impartial jury right in an era of widespread media coverage of criminal
54. Id.
55. Id. at $109-10$.
56. Id. at 110 .
57. Id. at 111
58. Id. at 112 .
59. Id. at 117 .
60. Id. at 111 .
61. Id.
62. Id. at 112 .
63. Id.
64. Id. (quoting Krulewitch v. United States, 336 U.S. 440, 453 (1949) (Jackson, J., concurring)).
65. Id. at $112-13$. 
trials epitomize the level of judicial uncertainty surrounding this issue as it made its way to the Supreme Court:

How best to protect accused persons from the prejudicial effect of newspaper publicity has been a matter of immense concern. In England, such publicity is largely curbed by the free use of the power of the courts to punish for contempt. In this country the course of treatment has been different. So far as the federal courts are concerned, there are important limitations upon the power to punish summarily for contempt. More fundamentally, it has been thought that this modern phenomenon of "trial by newspaper" is protected to a considerable degree by the constitutional right of freedom of the press. On this view there has been some fatalistic acceptance of "trial by newspaper", however unfortunate, "as an unavoidable curse of metropolitan living (like, I suppose, crowded subways)." The courts are then limited to doing what they can to insulate jurors from the prejudicial effect of such publicity, as by cautionary instructions or by the granting of continuances, or in some cases granting a change of venue. ${ }^{66}$

"Perhaps" the First Circuit hopefully suggested, "the Supreme Court has not spoken its last word upon this vexing subject." 67

\section{B. Sounding the Alarm-Irvin, Rideau, and Sheppard}

Eventually, the Supreme Court did speak on this vexing subject. ${ }^{68}$ In the early to mid-1960s, the Court decided three cases (two on habeas review) that squarely addressed when a trial court's failure to change venue in a criminal trial in the face of local prejudice amounted to a due process violation. Read together, these three casesIrvin v. Dowd, ${ }^{69}$ Rideau v. Louisiana, ${ }^{70}$ and Sheppard v. Maxwell ${ }^{71}$ - hold (albeit not without internal tension among Justices) that, as a matter of due process, trial courts may be constitutionally required to change venue where prejudice in the charging venue threatens a defendant's right to an impartial jury. ${ }^{72}$ A close reading of the

66. Id. at 113 (citations omitted) (quoting United States v. Leviton, 193 F.2d 848, 865 (2d Cir. 1951) (Frank, J., dissenting)).

67. Id.

68. See John A. Walton, From O.J. to Tim McVeigh and Beyond: The Supreme Court's Totality of Circumstances Test as Ringmaster in the Expanding Media Circus, 75 DenV. U. L. REV. 549, 556-57 (1998) ("The historical dichotomy between free press and fair trials predates television as the dominant medium of trial coverage. . . . Yet fair trial rights, though often touted as supreme in the federal courts, have not enjoyed a clear mandate of supremacy in cases where free press and fair trial rights have been in conflict. The manifestations of this ambiguous demarcation between free press and fair trial are evident in several areas, and have perplexed the Supreme Court for decades. . . . One ramification of this dichotomy is the regular attempts by the Court to balance the media's rights to pretrial reporting and the defendant's rights to a fair trial." (footnotes omitted)).

69. 366 U.S. 717 (1961).

70. 373 U.S. 723 (1963).

71. 384 U.S. 333 (1966).

72. Irvin, Rideau, and Sheppard were state court petitioners seeking relief on Fourteenth Amendment Due Process grounds, not under the Sixth Amendment. Irvin, 366 U.S. at 719; Rideau, 373 U.S. at 726; Sheppard, 384 U.S. at 335. The Court decided these cases before it extended Sixth Amendment jury trial 
multiple opinions produced in these early cases reveals deep-seated divisions among jurists about the relationship between the courts and the media on two critical issues: (1) whether increasingly pervasive media coverage of criminal trials posed a threat to the law's normative constructs of an impartial jury and a fair trial, ${ }^{73}$ and (2), if it did pose such a threat, whether and how the legal system should respond. ${ }^{74}$ Discord among Justices concerning these two points is evident in several aspects of the Supreme Court's early jurisprudence. Most critically, from the outset, the Justices did not agree on some fundamental threshold questions, such as exactly what constitutes proof of juror bias, and when, if ever, a presumption of bias is appropriate. ${ }^{75}$ These are differences that remain unresolved and that will continue to plague change-of-venue jurisprudence absent clear guidance from the Supreme Court. Despite the Justices' disagreements, there was little doubt that the cases all arose on a common area of conflict; the nature and volume of information reaching potential jurors about criminal trials forced the law to grapple with tensions between the constitutional impartial jury/local jury guarantees on one hand, and free press guarantees on the other.

Irvin v. Dowd was the Court's first decision recognizing that prejudicial pretrial publicity may deprive a defendant of a constitutionally fair trial in the charging venue. In 1954 and 1955, six murders were committed in the Evansville, Indiana area. ${ }^{76}$ The crimes received extensive local media coverage and "aroused great excitement and indignation throughout Vanderburgh County, where Evansville is located."77 After Irvin was arrested for the crimes, the prosecutor and the police issued press releases asserting he had confessed to the six murders. ${ }^{78}$ Irvin sought a change of venue from Vanderburgh County, citing "widespread and inflammatory publicity" surrounding his case. ${ }^{79}$ The trial court granted the motion, but to adjoining Gibson County, a rural area of approximately thirty thousand inhabitants. ${ }^{80}$ Irvin then moved for a change of venue from Gibson County and those motions were denied. ${ }^{81}$ The trial court conducted four

guarantees to state court proceedings in its 1968 decision in Duncan v. Louisiana. 391 U.S. 145, 148-50 (1968). Thus, these early cases considered the jury impartiality issue strictly as a Fourteenth Amendment due process question, not as a Sixth Amendment question.

73. See Irvin, 366 U.S. at $722-23$ (discussing increase in mass media and its effect on potential jurors); Rideau, 373 U.S. at 726 (explaining that "it was a denial of due process of law to refuse the request for a change of venue, after the people of Calcasieu Parish had been exposed repeatedly and in depth to the spectacle of Rideau personally confessing" and "[a]ny subsequent court proceedings in a community so pervasively exposed to such a spectacle could be but a hollow formality"); Sheppard, 384 U.S. at 362 (noting that "unfair and prejudicial news comment on pending trials has become increasingly prevalent. Due process requires that the accused receive a trial by an impartial jury free from outside influences").

74. See infra notes 85-94 and 108-15 and accompanying text for a discussion of the Justices' differing thoughts throughout this series of cases.

75. See infra notes 104-07 and accompanying text for a review of these issues in Rideau.

76. Irvin, 366 U.S. at 719.

77. Id. (quoting Irvin v. Dowd, 359 U.S. 394, 396 (1959)).

78. Id. at 719-20.

79. Id. at 720 .

80. Id. at 719-20.

81. Id. at 720 . 
weeks of voir dire in Gibson County, which revealed that almost ninety percent of Irvin's potential jurors held some opinion about Irvin's guilt "ranging in intensity from mere suspicion to absolute certainty." 82 The trial court eventually seated a jury of twelve that included eight jurors who thought Irvin was guilty. ${ }^{83}$ Irvin was convicted, sentenced to death, and he sought habeas relief in the Supreme Court. ${ }^{84}$

In an opinion authored by Justice Clark, a unanimous Court held that Irvin had been deprived of his Fourteenth Amendment due process rights because he was not tried before a panel of impartial jurors, which it defined as "indifferent jurors." ${ }^{15}$ The Court treated the popular news media as a proxy for the "current community pattern of thought" which it found "singularly revealing." $" 86$ The record, consisting of forty-six exhibits, in the Court's words, reflected "a barrage" of pretrial newspaper coverage "unleashed against [Irvin] during the six or seven months preceding his trial" that reached approximately ninety-five percent of the homes in Gibson County. ${ }^{87}$ In addition, local radio and television extensively covered details of the incidents, Irvin's arrest and conviction, as well as information extraneous to the charges at issue ${ }^{88}$ With respect to the effect of pretrial publicity on jurors, the Court held that constitutional impartiality does not require a juror to be "totally ignorant of the facts and issues involved" and that, given the contemporary nature of mass media, it would be unlikely that those most qualified to serve as jurors would be free from any impression of the case. ${ }^{89}$ Thus, the Court concluded, for purposes of determining bias, the question is not whether a juror holds a preconceived notion of guilt or innocence, but rather whether the juror "can lay aside his impression or opinion and render a verdict based on the evidence presented in court." 90 In light of the evidence of "a pattern of deep and bitter prejudice" in the community and the number of potential jurors who admitted prejudice against Irvin, the Court put no stock in the fact that the trial court had asked for, and received assurances from jurors that they could be fair. ${ }^{91}$

Notably, although Justice Clark acknowledged the contemporary state of media

\footnotetext{
82. Id. at 727 .

83. Id.

84. $I d$. at 718 .

85. Id. at 722 (internal quotation mark omitted). The Court reasoned that because "the right to jury trial guarantees to the criminally accused a fair trial by a panel of impartial, 'indifferent' jurors," Gibson County's "failure to accord an accused a fair hearing violates even the minimal standards of due process." Id.

86. Id. at 725 .

87. Id.

88. Id. at $725-26$.

89. $I d$. at 722 .

90. Id. at 723 .

91. Id. at 727-28. In assessing the assurances of impartiality that the jurors gave, the Court noted:

No doubt each juror was sincere when he said that he would be fair and impartial to petitioner, but the psychological impact requiring such a declaration before one's fellows is often its father. Where so many, so many times, admitted prejudice, such a statement of impartiality can be given little weight.
}

Id. at 728 . 
communications, ${ }^{92}$ the majority opinion made no reference to the free press/fair trial conflict underlying the case. Lest the elephant in the room go unmentioned, in his concurrence, Justice Frankfurter delivered a scathing commentary on what he perceived as the deleterious influence of the media on the administration of fair trials, going so far as to accuse the media of "poison[ing]" potential jurors' minds. ${ }^{93}$ His concurrence deserves quotation at length because of the subtext it provides for the Court's change-of-venue jurisprudence - namely, a singular inability to reach consensus in explaining what it means by a constitutionally impartial jury:

Of course I agree with the Court's opinion. But this is, unfortunately, not an isolated case that happened in Evansville, Indiana, nor an atypical miscarriage of justice due to anticipatory trial by newspapers instead of trial in court before a jury.

More than one student of society has expressed the view that not the least significant test of the quality of a civilization is its treatment of those charged with crime, particularly with offenses which arouse the passions of a community. One of the rightful boasts of Western civilization is that the State has the burden of establishing guilt solely on the basis of evidence produced in court and under circumstances assuring an accused all the safeguards of a fair procedure. These rudimentary conditions for determining guilt are inevitably wanting if the jury which is to sit in judgment on a fellow human being comes to its task with its mind ineradicably poisoned against him. How can fallible men and women reach a disinterested verdict based exclusively on what they heard in court when, before they entered the jury box, their minds were saturated by press and radio for months preceding by matter designed to establish the guilt of the accused. A conviction so secured obviously constitutes a denial of due process of law in its most rudimentary conception.

Not a Term passes without this Court being importuned to review convictions, had in States throughout the country, in which substantial claims are made that a jury trial has been distorted because of inflammatory newspaper accounts . . . . This Court has not yet decided that the fair administration of criminal justice must be subordinated to another safeguard of our constitutional system - freedom of the press, properly conceived. The Court has not yet decided that, while convictions must be reversed and miscarriages of justice result because the minds of jurors or potential jurors were poisoned, the poisoner is constitutionally protected in plying his trade. ${ }^{94}$

Two years after Irvin, the Court decided Rideau v. Louisiana. Rideau was arrested on suspicion of robbing a bank in Lake Charles, Louisiana, kidnapping three bank

92. See id. at 722-23 (commenting that the number of "widespread and diverse methods of communication" makes it nearly impossible to insulate prospective jurors from hearing about a case and forming an opinion as to the defendant's guilt or innocence before trial).

93. Id. at 729 (Frankfurter, J., concurring).

94. Id at 729-30. 
employees, and killing one of them. ${ }^{95}$ The day after he was arrested, a jailhouse interview between Rideau and the Sheriff of Calcasieu Parish, where Lake Charles is located, was recorded on film..$^{96}$ The interview lasted approximately twenty minutes; in it, Rideau confessed to the crimes. ${ }^{97}$ Later that day, the interview was broadcast via television in Lake Charles where, according to the majority opinion, around twentyfour thousand people in the community saw and heard it. ${ }^{98}$ The film was shown again the next day to an estimated audience of fifty-three thousand people and the following day to approximately twenty-nine thousand people. ${ }^{99}$ At the time, Calcasieu Parish had a population of approximately one hundred fifty thousand people. ${ }^{100}$

After he was charged, Rideau moved for a change of venue, which the trial court denied. ${ }^{101}$ Rideau was subsequently tried, convicted, and sentenced to death. ${ }^{102}$ The Supreme Court reversed his conviction. ${ }^{103}$ In a majority opinion authored by Justice Stewart, the Court held that the trial court's refusal to change venue after the people in the parish had been repeatedly exposed to the "spectacle" of Rideau confessing to the crimes was a denial of due process. ${ }^{104}$ Referencing the nature of television and "the onrush of an electronic age," the Court observed that the broadcast of Rideau's confession was, in effect, his trial, rendering any judicial proceeding in the community "a hollow formality." 105 Because the majority in Rideau found the circumstances surrounding the trial so egregious, it did not even bother to examine the voir dire record before concluding that due process required a trial before a jury drawn from a community that had not been exposed to the televised confession. ${ }^{106}$ These facts, the majority concluded, gave rise to a presumption that Rideau's jury was not impartial, so no evaluation of whether any individual juror was actually biased was necessary. ${ }^{107}$

Conspicuously, the Rideau majority opinion does not mention the Court's recent Irvin opinion, presumably because the majority did not consider Irvin and Rideau to be due process violations of the same strain. Of further note is that that Justice Clark, the author of the Court's Irvin opinion, dissented in Rideau. ${ }^{108}$ Stating that he would have

95. Rideau v. Louisiana, 373 U.S. 723, $723-24$ (1963).

96. Id. at 724 .

97. Id.

98. Id.

99. Id.

100. $I d$.

101. Id.

102. Id. at $724-25$.

103. Id. at 727 .

104. Id. at 726 .

105. Id.

106. Id. at 727 .

107. Id. Two years later, in Estes v. Texas, the Court applied Rideau to overturn the conviction of state court petitioner Billie Sol Estes. 381 U.S. 532, 538 (1965). There the Court found that media coverage of and interference with trial court proceedings "bombard[ed] . . . the community with the sights and sounds of" the pretrial hearing and "led to considerable disruption" in the proceedings themselves, denying the "judicial serenity and calm to which [Estes] was entitled." Id. at 536, 538.

108. Rideau, 373 U.S. at 727 (Clark, J., dissenting). 
had no hesitation vacating Rideau's conviction had he been a federal defendant under the Supreme Court's supervisory powers, Justice Clark found that Rideau's trial did not fall below the constitutional minimum fair trial requirements. ${ }^{109}$ Justice Clark agreed with the general proposition that a defendant is deprived of due process by a trial in an environment permeated with hostility but, in his opinion, Rideau had not rebutted the presumption that his jury was impartial because there was no nexus between the broadcast of the prejudicial information and Rideau's trial two months later. ${ }^{110}$ Unlike the majority, Justice Clark compared the record in Rideau with the record in Irvin. ${ }^{111}$ The latter, he observed, included an extensive and quantifiable record of the number and percentage of jurors who held opinions about Irvin's guilt. ${ }^{112}$ In contrast, the record in Rideau established only that three of the people on the jury had seen the televised interview shown two months before trial. ${ }^{113}$ Critically, in Justice Clark's view, there was no record that jurors who saw the interview held any opinion as to Rideau's guilt, and those jurors had testified that they "could lay aside any opinion[s]" and decide the case solely on the evidence. ${ }^{114}$ This early split over whether and how a defendant must establish a nexus between the dissemination of prejudicial information and an impact on the jury, and what weight trial courts should give to jurors' self-assessments of impartiality, remains unresolved to this day. ${ }^{115}$

The Court decided Sheppard v. Maxwell in 1966, three years after Rideau. ${ }^{116}$ Sheppard was convicted of murdering his pregnant wife in their home in Bay Village, Ohio, a suburb of Cleveland. ${ }^{117}$ Sheppard's trial was accompanied by an extraordinary level of sensationalistic and scurrilous media coverage. ${ }^{118}$ Sheppard was convicted in a trial described as a media circus, in which the trial court, for all practical purposes, gave the media free run of the courtroom. ${ }^{119}$ On habeas review, the Court agreed that Sheppard did not receive a constitutionally fair trial and overturned his conviction. ${ }^{120}$ Justice Clark, who had authored Irvin and dissented in Rideau, was back in the majority in Sheppard and authored the Court's opinion. ${ }^{121}$ Noting that prejudicial news coverage

109. Id. at $728-29$

110. Id. at $729-30$

111. Id. at $730-31$

112. Id. at 730

113. Id. at 732

114. Id. (quoting State v. Rideau, 137 So. 2d 283, 295 (La. 1962)). In Justice Clark's view, if jurors testify they can be impartial, Courts should "not lightly" discard those assurances except where a case presents "unusually" compelling circumstances, as in Irvin. Id. at 733.

115. See infra notes 296-300 and accompanying text for a discussion of how the Justices of the Supreme Court and judges of the lower courts collectively authored five different opinions in Skilling on the proper application of the law on pretrial publicity and juror impartiality.

116. Sheppard v. Maxwell, 384 U.S. 333 (1966).

117. Id. at 335-36.

118. Id. at $338-42$

119. Id. at $342-45$.

120. Id. at 363

121. Only Justice Black dissented in Sheppard and he did so without comment. Id. (Black, J., dissenting). 
of pending trials had become "increasingly prevalent" and that due process requires a trial by an impartial jury, the Sheppard Court placed the responsibility for safeguarding this right squarely with the courts:

From the cases coming here we note that unfair and prejudicial news comment on pending trials has become increasingly prevalent. Due process requires that the accused receive a trial by an impartial jury free from outside influences. Given the pervasiveness of modern communications and the difficulty of effacing prejudicial publicity from the minds of the jurors, the trial courts must take strong measures to ensure that the balance is never weighed against the accused. ${ }^{122}$

Although the Court noted the duty of reviewing courts "to make an independent evaluation of the circumstances," it admonished trial courts to prevent the denial of due process in the first instance: "we must remember that reversals are but palliatives; the cure lies in those remedial measures that will prevent the prejudice at its inception." 123 The trial court in Sheppard's case, the Court concluded, had failed in its duty "to protect Sheppard from the inherently prejudicial publicity which saturated the community and to control disruptive influences in the courtroom." 24

Although Irvin, Rideau, and Sheppard are often cited and discussed together as pretrial publicity cases, important distinctions exist among them. The Court granted Irvin's writ of habeus corpus based on a showing of actual prejudice, ${ }^{125}$ but granted postconviction relief in Rideau and granted the writ of habeus corpus in Sheppard despite a lack of evidence of actual prejudice. ${ }^{126}$ However, unlike Irvin and Rideau, Sheppard was not, strictly speaking, a pretrial publicity case. In Sheppard, the presence of reporters and television cameras in the courtroom caused significant disruptions in the trial proceedings. This factor, as much as pretrial publicity, led the Court to conclude that Sheppard's due process rights had been violated without requiring evidence that Sheppard had been prejudiced. ${ }^{127}$ Rideau's conviction, therefore, is the only one of the three in which the Supreme Court overturned a conviction or granted a writ of habeus corpus based solely on local conditions in the community without a showing of actual prejudice. ${ }^{128}$

122. Id. at 362 (majority opinion).

123. Id. at $362-63$.

124. Id. at 363 .

125. Irvin v. Dowd, 366 U.S. 717, 727-28 (1961).

126. Rideau v. Louisiana, 373 U.S. 723,727 (1963); Sheppard, 384 U.S. at 363.

127. Sheppard, 384 U.S. at 363.

128. Following Sheppard, in 1971 the Court decided Groppi v. Wisconsin, which involved a challenge to a state statute preventing a change of venue in misdemeanor cases, regardless of the extent of local prejudice. Groppi v. Wisconsin, 400 U.S. 505, 511-12 (1971). The Court held that the statute violated the Fourteenth Amendment right to an impartial jury and that, in some cases, a change of venue may be the only constitutionally adequate remedy for prejudicial pretrial publicity. Id. at 510-11. 


\section{Retreat and Retrenchment-Murphy, Patton, Mu'Min}

Murphy v. Florida, ${ }^{129}$ decided in 1975 , presented the question of whether jurors who have been exposed to extensive information about a defendant's prior criminal record are impartial for constitutional purposes. ${ }^{130}$ Jack Roland Murphy was a notorious thief who had made a name for himself through his involvement in the theft of the Star of India sapphire from a New York museum in 1964. ${ }^{131}$ Murphy was later arrested in 1968 for a Miami Beach home robbery, and this event generated extensive media coverage. ${ }^{132}$ Before he was brought to trial in Dade County, where Miami Beach is located, Murphy was indicted on two counts of murder in Broward County, another Florida county. ${ }^{133} \mathrm{He}$ was subsequently declared incompetent to stand trial and committed to a hospital. ${ }^{134}$ After that, he was adjudged competent to stand trial for one count of murder in Broward County and convicted of that charge. ${ }^{135}$ Then, Murphy pleaded guilty to federal charges of conspiring to transport stolen securities in interstate commerce. ${ }^{136}$ After the Broward County trial, the state refiled the robbery indictment in Dade County and that matter went to trial, giving rise to the constitutional challenge that eventually made its way to the Supreme Court. ${ }^{137}$ All of this information about Murphy's criminal history was extensively reported in the media, and during voir dire in the Dade County matter, jurors indicated they were aware of it. ${ }^{138}$ Murphy moved to change venue based on prejudicial pretrial publicity; his motion was denied and he was convicted. ${ }^{139}$ When his habeas challenge reached the Supreme Court, Justice Marshall, writing for the majority, found no constitutional violation. ${ }^{140}$ Despite a voir dire record that established jurors' knowledge of Murphy and his prior crimes (and, according to Justice Brennan's dissent, actual bias against Murphy), the Court affirmed his conviction. ${ }^{141}$

Murphy presented the Court with an opportunity to extend the logic of its earlier holdings that extensive media dissemination of inadmissible and prejudicial information in the charging venue may impact the ability of jurors in that venue to be impartial. Instead, the Court interpreted its pretrial publicity precedents to require more than mere exposure to extraneous prejudicial information about the case to satisfy the

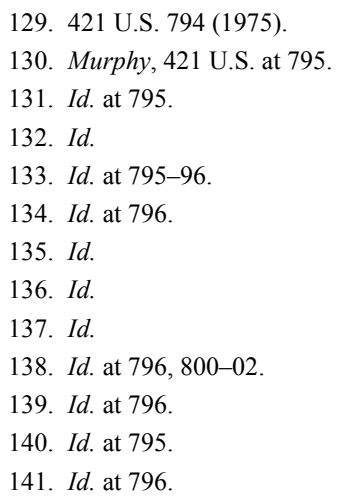


constitutional change-of-venue standard. ${ }^{142}$ Although the primary focus of Irvin, Rideau, and Sheppard was the potentially corrupting influence of extraneous information on jurors' ability to be impartial (specifically media coverage of the defendant's past and the circumstances of the crime), the Murphy majority distinguished these precedents as cases in which the convictions were "obtained in a trial atmosphere that had been utterly corrupted by press coverage." 143 Even though a unanimous Court in Irvin had relied on popular media coverage as proxy for the "current community pattern of thought," 144 the Murphy Court held that the relevant inquiry is not just whether a juror has been exposed to information about a defendant's prior convictions or to news accounts of the crime with which he is charged, but also whether the proceedings in the defendant's case "were entirely lacking in the solemnity and sobriety to which a defendant is entitled in a system that subscribes to any notion of fairness and rejects the verdict of a mob." ${ }^{145}$ An inquiry, the Court held, that is to be evaluated under the "totality of circumstances." 146

Murphy is an important milepost in the Court's change-of-venue jurisprudence for several reasons. First, as noted above, it reconfigured the due process inquiry as not solely concerned with the impact of extraneous information on juror impartiality (i.e., the effect of publicity on jurors' ability to base a verdict solely on trial evidence), but as also concerned with the dignity of court proceedings. Second, it established that the due process inquiry must be based on the totality of the circumstances, a standard that considers the voir dire record, the atmosphere of the community at the time of the trial, and the length to which the trial court must go to select impartial jurors-a standard that has proven to be highly elastic in practice. ${ }^{147}$ And, third, it explicitly acknowledged that concerns with timely prosecutions provide a legitimate countervailing argument against a change of venue. ${ }^{148}$

142. Walton, supra note 68 , at 565 ("When applying the inherent prejudice standard, the Court initially took the position that the rights of criminal defendants in highly publicized cases must be protected through strong measures that would not favor the press. Within ten years, however, the Court appeared to retreat from these precedents, possibly evidencing a concern that these opinions provided too broad a basis for challenging criminal convictions in an atmosphere where trials were receiving increasing media attention." (footnote omitted) (citing Sheppard v. Maxwell, 384 U.S. 333, 362 (1966))).

143. Murphy, 421 U.S. at 798.

144. Irvin v. Dowd, 366 U.S. 717, 725 (1961).

145. Murphy, 421 U.S. at 799.

146. Id. at 799 .

147. Two years after Murphy, the Court decided Dobbert v. Florida, in which it again rejected the argument that extensive media coverage or community knowledge, standing alone, is sufficient to establish that a trial in a particular venue was unfair, and interpreted its earlier cases to require either a showing that (1) a trial setting was inherently prejudicial, or (2) that the jury selection process permitted an inference of actual prejudice to establish a due process violation. Dobbert v. Florida, 432 U.S. 282, 302 (1977).

148. Murphy, 421 U.S. at 801 n.4 ("To ignore these real differences in the potential for prejudice [between mere familiarity with petitioner or his past and an actual predisposition] would not advance the cause of fundamental fairness, but only make impossible the timely prosecution of persons who are well known in the community, whether they be notorious or merely prominent."). 
In Patton v. Yount, ${ }^{149}$ decided in 1984, the Court again took up, in its words, "the problem of pervasive media publicity that now arises so frequently in the trial of sensational criminal cases." 150 Yount, a former high school mathematics teacher, was charged in Clearfield County, Pennsylvania with sexually assaulting and murdering an eighteen-year-old female former student. ${ }^{151}$ Yount was tried and convicted in 1966, his conviction was reversed, and he was retried in 1970.152 At his second trial, Yount moved several times before, during, and after voir dire for a change of venue on the ground of prejudicial pretrial publicity. ${ }^{153}$ The trial court denied his motions; he was found guilty of murder and sentenced to life imprisonment. ${ }^{154}$

Yount sought federal habeas relief on the ground that the denial of a change of venue had violated his right to due process. ${ }^{155}$ The district court denied his petition, but a three-judge panel of the Third Circuit reversed. ${ }^{156}$ The circuit court opinion in Patton provides a vatic foreshadowing of the fault lines that have come to fragment change-ofvenue jurisprudence - the case was decided by a panel that produced three separate opinions (a lead opinion and two concurring opinions). ${ }^{157}$ The Third Circuit characterized the pretrial publicity that accompanied Yount's case as extensive and found that it presented a great potential for prejudice because it "revealed prejudicial information 'never heard from the witness stand' in the second trial."158 Further, although the Third Circuit did not find that the widespread dissemination of this information gave rise to a presumption of prejudice, it did find that it had "poisoned the 'general atmosphere of the community"' where Yount was retried and that the voir dire record before it "more strongly resemble[d] that of Irvin than that of Murphy."159

District Judge Stern, sitting by designation, ${ }^{160}$ and Circuit Judge Garth filed separate concurring opinions. Judge Stern, in a sharply worded opinion, wrote: "[u]nder any test reflecting even the most minimal respect for the values embodied in the sixth amendment, we would be compelled to invalidate this conviction."161 His specific

149. 467 U.S. 1025 (1984)

150. Patton, 467 U.S. at 1031.

151. Id. at $1026-27$.

152. Id. at 1027

153. Id.

154. Id. at $1027-28$.

155. Id. at 1028

156. Yount v. Patton, 710 F.2d 956 (3d Cir. 1983), rev'd 467 U.S. 1025 (1984).

157. Id.

158. Id. at 969 (quoting Sheppard v. Maxwell, 384 U.S. 333, 356 (1966)).

159. Yount, 710 F.2d at 970-71. (quoting Murphy v. Florida, 421 U.S. 794, 802 (1975)); see also Patton, 467 U.S. at 1029-30 (noting that the media reported on Yount's confession to a brutal murder and on his prior conviction for the crime, which had been reversed due to a violation of Miranda $v$. Arizona and during voir dire, seventy-seven percent of Yount's prospective jurors acknowledged they would carry an opinion into the jury box, and eight of the fourteen seated jurors and alternates admitted they had formed an opinion as to his guilt.).

160. The fact that Judge Stern was a sitting trial court judge with firsthand voir dire experience lends a certain authenticity to his observations and frustrations with the existing pretrial publicity standard.

161. Yount, 710 F.2d at 972 (Stern, J., concurring). 
concern, however, was with a constitutional standard that "renders constitutional trials taking place under circumstances only slightly less shocking than those presented in this case." 162 In Judge Stern's view, the Irvin test for unconstitutional bias could not be reconciled with the requirements of the Sixth Amendment and should have been abandoned for a simpler and more reliable inquiry. ${ }^{163} \mathrm{He}$ proposed a test that would disqualify any juror who represented that he or she had formed an opinion as to the defendant's guilt or innocence, without requiring further inquiry into whether that juror could set aside his or her opinion as to guilt (as permitted under the Irvin standard). ${ }^{164}$ Even if a promise to lay aside an opinion is either believable or enforceable, he asserted, none "of us would want to gamble our freedom on the ability of a person to erase a preformed opinion as to guilt."165

Judge Garth concurred separately to make clear that he believed a new trial was required because there was one juror who admitted during voir dire that he would find it difficult to change his mind about Yount's guilt absent facts establishing his innocence. ${ }^{166}$ Judge Garth concluded that this raised a presumption of the juror's partiality and established that this juror was improperly impaneled. ${ }^{167}$ Because Judge Garth concluded that the due process violation was limited to seating a single juror who should have been presumed biased, he disagreed with the majority opinion that pretrial publicity required a change of venue. ${ }^{168}$

Thus, three circuit court judges agreed that Yount had been deprived of a constitutionally fair trial, but for different reasons. All three judges agreed that unlike Rideau, there was not enough evidence to presume prejudice in the entire community, but that like Irvin, Yount's jury was exposed to highly prejudicial information, including information about his first trial. They further agreed that, under Irvin, the nature of the publicity and the voir dire record was such that the court could not give credence to jurors' assurances that they could set aside their opinions about Yount's guilt. ${ }^{169}$ However, one concurring judge questioned the entire premise that any juror who had formed an opinion as to the defendant's guilt should ever be seated (as permitted under Supreme Court precedent) regardless of whether the juror avers he or

\section{Id.}

163. Id. at $974-75$.

164. Id. at 975 .

165. Id. at 973. Judge Stern further rejected the notion that the Irvin test was necessary because he did not agree it would be impossible to impanel a jury without it:

I simply refuse to believe that in a land as populous as ours, where potential jurors abound, the only way to assemble a group of 12 impartial persons is to allow those with advance opinions to sit as long as they give a proper incantation of their ability to lay aside those opinions. If a jury cannot be selected without resort to persons with preformed views of a defendant's guilt, it should be a simple matter to transfer the case to another county.

Id. at 974 .

166. Id. at 975-76 (Garth, J., concurring).

167. Id. at 975 .

168. Id.

169. Id. at 972 (majority opinion). 
she can set aside that opinion. ${ }^{170}$ And the other concurring judge identified the due process violation as the seating of one juror who had expressed a strong opinion about Yount's guilt. ${ }^{171}$

Yount fared less well in the Supreme Court, which reversed the Third Circuit. ${ }^{172}$ At the outset, the Patton Court discounted the Third Circuit's reliance on Irvin, intimating that the opinion had somehow become outdated. ${ }^{173}$ In truth, Irvin was and remains good law because the Court has never overruled it. Furthermore, the facts in Patton were remarkably similar to those in Irvin, if not more compelling. Like Irvin, Yount confessed to his crime. ${ }^{174}$ But not only did he confess to his crime (a brutal murder), his confession was entered into evidence at his first trial where the jury rejected his insanity defense and found him guilty of murder and rape - all information that was not admissible at Yount's second trial, but to which the jurors in Yount's second trial were exposed to before the second trial began. ${ }^{175}$ Clearfield County, Pennsylvania, the community from which Yount's jury was drawn, although larger than the county in which Irvin was tried, was a small, rural jurisdiction. ${ }^{176}$ The voir dire in Patton established that all but two of 163 potential jurors had heard of the case and seventy-seven percent admitted they would carry an opinion into the jury box. ${ }^{177}$ In comparison, sixty-two percent of Irvin's potential jurors were dismissed for cause because they had fixed opinions concerning the petitioner's guilt. ${ }^{178}$ Eight of the fourteen jurors and alternates actually seated in Yount's trial admitted that at some time they had formed an opinion as to Yount's guilt, ${ }^{179}$ as did eight out of twelve of Irvin's jurors. ${ }^{180}$

Rather than confront the growing discord in its change-of-venue jurisprudence, as epitomized by the Third Circuit's three separate opinions, the Patton majority faulted the Third Circuit for failing to properly weigh all the circumstances in the case. ${ }^{181}$ Rather than acknowledging the undeniable similarities between the facts and

170. Id. at 975 (Stern, J., concurring).

171. Id. at 975 (Garth, J., concurring).

172. Patton v. Yount, 467 U.S. 1025, 1031 (1984).

173. Id. Justice Powell wrote the opinion for a six-Justice majority in Patton which referred to Irvin as a leading case at the time: "That decision, a leading one at the time, held that adverse pretrial publicity can create such a presumption of prejudice in a community that the jurors' claims that they can be impartial should not be believed." Id.

174. Id. at 1027 .

175. Before Yount's second trial in 1970, the trial court suppressed his written confessions and that portion of the oral confession that was obtained after he was legally in custody and the prosecution dismissed the rape charge. $I d$.

176. See id. at 1041 (Stevens, J., dissenting) (describing Clearfield County as "a rural county, with a population of about 70,000"). Irvin was tried in Gibson County, Illinois, a rural area with approximately thirty thousand citizens. Irvin v. Dowd, 366 U.S. 717, 719 (1961).

177. Patton, 467 U.S. at 1029.

178. Id.

179. Id.

180. Irvin, 366 U.S. at 727 .

181. Patton, 467 U.S. at 1031-32. 
circumstances in Irvin and Patton, the Court held that the Third Circuit erred in only focusing on some factors important to the Irvin decision. ${ }^{182}$ It held, for example, that Patton could be distinguished from Irvin by the passage of time between Yount's first and second trial because the second trial was not immediately preceded by a "barrage of inflammatory publicity." 183 The Court found that Yount's case was more like Murphy's, where the passage of time between the dissemination of prejudicial information and the time of trial was a relevant consideration. ${ }^{184}$ Relying on Murphy and resting its constitutional analysis on the platitude "[t]hat time soothes and erases," in Patton the Court explicitly designated the passage of time as a factor relevant to the impact of pretrial publicity on juror impartiality. ${ }^{185}$ In short, the Court injected yet another factor into the totality of the circumstances inquiry and specifically indicated that this particular factor-the passage of time-will likely suffice to deny or uphold the denial of a change of venue based on pretrial publicity in most instances. ${ }^{186}$ And, in contradiction of the Court's earlier observation in Rideau about the ineffectiveness of voir dire in detecting juror bias in cases accompanied by high levels of publicity, the Court stated that it was "fair to assume" that voir dire "usually identifies bias." 187

Justice Stevens dissented, joined by Justice Brennan. ${ }^{188} \mathrm{He}$ believed that the testimony of one juror - that the juror would need to be persuaded of Yount's innocence - clearly raised a presumption of bias and that the trial judge committed manifest error by impaneling that juror. ${ }^{189}$ Rather than extend special deference to state courts on habeas review of these issues, as the Court had done, Justice Stevens noted that there was, in fact, a "special reason to require independent review [in cases] that arouse[] the passions of the local community in which an elected judge is required to preside." 190 "Unlike an appointed federal judge with life tenure," he observed, "an elected judge has reason to be concerned about the community's reaction to his disposition of highly publicized cases." 191

The final installment in the Court's change-of-venue jurisprudence before Skilling came in Mu'Min v. Virginia, ${ }^{192}$ where the Court considered the constitutional adequacy

182. Id.

183. Id. at $1032-33$.

184. Id. at 1035 n.11.

185. Id. at 1034. "The voir dire testimony revealed that this lapse in time had a profound effect on the community and, more important, on the jury, in softening or effacing opinion." Id. at 1033. In Yount's case, the Court held that this passage of time "clearly rebut[ted] any presumption of partiality or prejudice that existed at the time of the initial trial[,]" and that "[t]here was fair, even abundant, support for the trial court's findings that between the two trials of this case there had been 'practically no publicity given to this matter through the news media." Id. at 1035 (quoting Appendix at 268a, 265a).

186. Id.

187. Id. at 1038 .

188. Id. at 1040. Justice Marshall took no part in the case. Id.

189. Id. at 1052 (Stevens, J., dissenting).

190. Id.

191. Id. at $1052-53$.

192. 500 U.S. 415 (1991). 
of jury voir dire in identifying and eliminating jury bias. ${ }^{193}$ Mu'Min was charged with capital murder committed after escaping briefly from prison. ${ }^{194}$ The pretrial publicity accompanying his case included information about his criminal record, prison infractions, and failed attempts to secure parole. ${ }^{195} \mathrm{Mu}$ 'Min sought to have content questions posed to prospective jurors who acknowledged being exposed to information about his case either though the media or in conversations (i.e., questions about specific information they had acquired). ${ }^{196}$ The state trial court denied the request and accepted jurors' assertions that they could be impartial even though they had been exposed to information about Mu'Min's case. ${ }^{197}$ To ascertain bias, Mu'Min's trial court divided prospective jurors into groups of four, asked them collectively whether they could be impartial, and interpreted silence as assent. ${ }^{198}$

A divided Supreme Court of Virginia affirmed, concluding that Mu'Min did not have a constitutionally cognizable right to pose content questions to prospective jurors. ${ }^{199}$ Applying Supreme Court precedents, four justices of the seven-member state court held it was sufficient that no member of the panel indicated he or she had formed an opinion based upon the information acquired before trial, "and all had affirmed on oath that they could stand indifferent in the cause."200 Three justices dissented. ${ }^{201}$ Citing an "unusual" amount of pretrial publicity and the obvious difficulty of establishing a record of juror bias without being allowed to inquire as to the impact and effect of pretrial publicity, the three Justices would have reversed and remanded for a new trial. ${ }^{202}$ To the dissenting state court justices, it was not sufficient to conclude that each juror exposed to pretrial publicity was impartial, particularly because the trial court did not engage in any meaningful exchange with individual jurors to test the assertion that he or she could be impartial. ${ }^{203}$

The Supreme Court, foreshadowing its inability to agree on some very basic premises concerning the nature of jury bias in Skilling nineteen years later, split five-tofour and produced four separate opinions upon Mu'Min's appeal. ${ }^{204}$ Chief Justice Rehnquist authored the majority opinion, which Justices White, O'Connor, Scalia and Souter joined. ${ }^{205}$ The majority found no constitutional error in the trial court's failure to follow up with individual jurors who acknowledged exposure to information about Mu'Min and found it was constitutionally permissible to simply accept jurors' self-

193. Mu'Min, 500 U.S. at 417.

194. Id.

195. Id. at 418 .

196. Id. at 419.

197. Id.

198. Id. at 419-21.

199. Mu'Min v. Commonwealth, 389 S.E.2d 886, 893 (Va. 1990).

200. Id.

201. Id. at 898 (Whiting, J., dissenting).

202. Id. at 899 .

203. Id. at 902 .

204. Mu'Min v. Virginia, 500 U.S. 415, 417 (1991).

205. Id. 
assessment of their ability to be impartial. ${ }^{206}$ With respect to pretrial publicity, the majority found that reliance on the trial court's judgment made particularly "good sense" because the judge is from the locale of the trial and will have insight into the publicity and its effects. ${ }^{207}$ The majority acknowledged that the Court's precedents allowed for a presumption of prejudice, but concluded that there was no "wave of public passion" in Mu'Min's case that would support the presumption. ${ }^{208}$ Under the constitutional standard, the Court held "[t]he relevant question is not whether the community remembered the case, but whether the jurors . . had such fixed opinions that they could not judge impartially the guilt of the defendant." ${ }^{209}$ And trial courts, the majority held, are not constitutionally required to do more than secure jurors' assurances as to their impartiality to meet this standard. ${ }^{210}$

In dissent, Justices Marshall, Blackmun, and Stevens criticized the majority for turning "a critical constitutional guarantee-the Sixth Amendment's right to an impartial jury - into a hollow formality." 211 The dissent observed that "the only firm conclusion that can be drawn from our impartial-jury jurisprudence is that a prospective juror's own 'assurances that he is equal to this task cannot be dispositive of the accused's rights.",212 "It is simply impossible," the dissent continued, "to square [the Court's] decision with the established principle that, where a prospective juror admits exposure to pretrial publicity, the trial court must do more than elicit a simple profession of open-mindedness before swearing that person into the jury." 213

Justice Kennedy dissented by separate opinion. He drew a distinction in the Court's jurisprudence between allegations that potential jurors were biased as a result of pretrial publicity on one hand, and the "quite separate problem" of a defendant tried in an "atmosphere so corruptive of the trial process that we will presume a fair trial could not be held, nor an impartial jury assembled."214 In Justice Kennedy's view, Mu'Min's case clearly fell in the former category, and the Court's inquiry should have turned on whether the seated jurors were actually impartial, and whether the trial court's voir dire of the jurors who were exposed to information about the case was adequate. $^{215} \mathrm{He}$ found that the voir dire in Mu'Min-was inadequate to permit an informed ruling that the jurors impaneled were qualified and would have reversed on

206. Id. at 431-32.

207. Id. at 427. The Mu'Min Court's "good sense" argument for relying on the judgment of local judges stands in stark contrast to Justice Stevens' observation in Patton about the pressures faced by elected judges (which would include most state court judges) in resolving high-publicity cases.

208. Mu'Min, 500 U.S. at 429.

209. Id. at 430 (omission in original) (quoting Patton, 467 U.S. at 1035).

210. See id. (finding that the trial court need only find impartiality under the constitutional standard; ignorance of the facts and issues involved is not required).

211. Id. at 433 (Marshall, J., dissenting).

212. Id. at 440 (quoting Murphy v. Florida, 421 U.S. 794, 800 (1974)).

213. Id.

214. Id. at 448 (Kennedy, J., dissenting).

215. Id. at 449 . 
that ground..$^{216}$

\section{Taking Stock — an Unpredictable and Uneven Justice}

Mu'Min, the Court's last word on pretrial publicity before Skilling, produced a fractured opinion with Justices unable to agree on even the most fundamental questions involved. For example, there is little clarity on: (1) how much deference trial courts should receive in choosing methods for determining whether a potential juror has a fixed opinion about the defendant's guilt, (2) how much evidence is required to uphold a trial court's determination that a juror is not actually biased, (3) what credence courts should give jurors' self-evaluations of their own bias, and (4) how great a "wave of public passion" must be before a reviewing court will override a trial court's determination that a juror can set aside an opinion on guilt or innocence. ${ }^{217}$ By failing to resolve these issues and establishing that trial court change-of-venue decisions would be virtually unreviewable after Mu'Min, for all practical purposes, the Court left this area of law to develop in the lower courts on a case-by-case basis under the highly pliable totality of the circumstances inquiry. ${ }^{218}$

In practice, the totality of the circumstances inquiry has proven to permit so much decisional latitude that it has produced a change-of-venue jurisprudence with little or no predictive or prudential value. ${ }^{219}$ Under this approach, trial courts can rest their pretrial publicity decisions on a myriad of factors, including individual and even idiosyncratic definitions of impartiality, with little danger of being reversed. ${ }^{220}$ The

216. Id. at 452 .

217. Id. at 428 (quoting Irvin v. Dowd, 366 U.S. 717, 728 (1961))

218. Cf. Walton, supra note 68, at 587-88 (characterizing Mu'Min as a clown tossing "confetti, not water, on the flame of injustice" in the context of a media circus); see also Robert Hardaway \& Douglas B. Tumminello, Pretrial Publicity in Criminal Cases of National Notoriety: Constructing a Remedy for the Remediless Wrong, 46 AM. U. L. REV. 39, 64 \& n.213 (1996) ("The 'totality of the circumstances' test presumes that the law will develop case-by-case.").

219. See Walton, supra note 68 at 579-81 (noting that the case law in this area has failed to provide clear guidance). Walton further explains:

After Murphy, the "totality of the circumstances" test can be viewed as the Court's Jell-O remedy for the unknown future of pretrial publicity. Like Jell-O, it appears solid in that it requires a court ... to look "to any indications in the totality of the circumstances that petitioners' trial was not fundamentally fair." Yet because the test grants the Court discretion to rule based on individual factors in each case, like Jell-O, it wiggles or changes when a defendant attempts to grab hold of an opinion as precedent. Each new case presents, in "totality," a new set of circumstances. Since the totality of circumstances, as opposed to a predetermined set of factors, are determinative, any one factor from prior cases and precedents may be discounted or offset by another.

Id. at 579 (footnotes omitted) (quoting Murphy v. Florida, 421 U.S. 794, 799 (1975); Antonin Scalia, The Rule of Law as a Law of Rules, 56 U. CHI. L. REV. 1175, 1177 (1989)). See also Gary A. Hengstler, Sheppard v. Maxwell Revisited -Do the Traditional Rules Work for Nontraditional Media?, 71 LAW \& CONTEMP. PROBS. 171, 180 (2008) ("Certainly with respect to balancing First and Sixth Amendment rights and values under our system, the answers are not readily apparent." But, "[f]orty-plus years after Sheppard v Maxwell, and with the sweeping changes in the media, [clarity on these issues] is not an unreasonable request.").

220. Indeed, trial courts have been afforded so much discretion that some apparently feel no need to follow established Supreme Court precedent. See, e.g., United States v. Kohring, No. 3:07-cr-00055 JWS, 
result has been widely divergent outcomes on similar facts or issues among courts. ${ }^{221}$ Consideration of several characteristics of contemporary change of venue illustrates its disjoined nature. First, successful venue challenges under the federal constitutional pretrial publicity standard have become increasingly rare even though modern jurors are subject to far more pervasive, comprehensive, and rapid mass communications than jurors in previous decades. ${ }^{222}$ Second, although federal courts have overturned state convictions under the pretrial publicity standard, it appears that no federal district court denial of a change of venue has ever been reversed on appeal in a reported decision. ${ }^{223}$ Third, even given the fact-specific nature of venue challenges, there is no discernible consistency in courts' application of the pretrial publicity standard in similar situations. ${ }^{224}$ And, fourth, the results that trial courts reach, and reviewing courts uphold, often run contrary to the wealth of well-established social science research routinely presented to trial courts in support of change-of-venue motions. ${ }^{225}$

It is indisputable that the volume of information about criminal cases that contemporary potential jurors are exposed to has been amplified by near-universal exposure to an extraordinary amount of nonstop information, particularly on the

2007 WL 2949528, at $* 23$ (D. Alaska Oct. 9, 2007) (denying a motion to change venue in part on personal observation that, notwithstanding Irvin, potential jurors probably are not really affected by pretrial publicity). The Kohring court further noted:

The fact is that the public at large is simply not as attuned to local news as it was in an earlier era when Irwin [sic] was decided . . . . To put it bluntly, a surprising number of prospective jurors are just not interested in, and do not follow, local news. Many don't even read local newspapers. Many do not watch the local news on television. Among those who do read the newspaper, many simply glance at the local news headlines while moving on to areas of interest such as sports or gardening. Many who watch television are looking for entertainment programs, not local news. To be sure, there are still many citizens who seek to stay informed about local events, but the tacit assumption that there is nearly universal interest in local news which underpins cases like Irwin [sic] . . is an increasingly questionable assumption.

Id.

221. Compare United States v. McVeigh, 918 F. Supp. 1467, 1470 (W.D. Okla. 1996) (presuming a community-wide bias based on local news coverage of terroristic event and granting a change of venue), with United States v. Lindh, 212 F. Supp. 2d 541, 548-49 (E.D. Va. 2002) (declining to presume a community-wide bias based on personal connections to terrorism victims and denying a change of venue).

222. See infra notes 226-28 and accompanying text for a discussion of the modern media and its effect on juror impartiality.

223. This writer is aware of only one reversal of a federal trial court denial of a change of venue in a reported decision-United States v. Campa, 419 F.3d 1219 (11th Cir. 2005). The panel decision in that case, however, was reversed and vacated en banc. United States v. Campa, 459 F.3d 1121, 1144 (11th Cir. 2006) (holding that the district court did not abuse its discretion when it found that the pretrial publicity surrounding the defendants' trial was not so inflammatory and pervasive that it warranted a change of venue).

224. See infra notes 242-47 and accompanying text for an illustration of courts' inconsistent application of the standard in terrorism cases.

225. Compare Mu'Min v. Virginia, 500 U.S. 415, 419-20 (1991) (relying on potential jurors' selfassessments of impartiality), with Christina A. Studebaker \& Steven D. Penrod, Pretrial Publicity: The Media, the Law, and Common Sense, 3 Psychol. PUB. POL'Y \& L. 428, 433-38 (1997) (describing the propensity of self-assessed impartial jurors to return guilty verdicts). 
Internet. ${ }^{226}$ Not only has the amount of information potential jurors are exposed to increased, the nature and reliability of that information has changed as well. Unlike traditional information sources like newspapers, radio and television, the Internet provides a forum for amateur publication of information unfiltered by a professional news organization or a fact-checking process. Thus, contemporary potential jurors are potentially exposed to more pretrial publicity than their predecessors and the increased information they are exposed to may be of uncertain origin, accuracy, and reliability. ${ }^{227}$ Given that the constitutional pretrial publicity standard has ostensibly remained unchanged for decades and that it rests on the basic premise that the more inflammatory pretrial coverage a juror is exposed to, the less likely that juror can be constitutionally impartial, one would reasonably expect to see more, not fewer, successful contemporary venue challenges. ${ }^{228}$

Successful venue challenges under the federal constitutional pretrial publicity standard, however, are extraordinarily rare. ${ }^{229}$ Lower federal courts have overturned only a handful of state convictions on habeas review under the federal constitutional standard in reported decisions. ${ }^{230}$ And there have been very few successful change-of-

226. The recent state court murder prosecution of Casey Anthony for the death of her daughter, dubbed the "first major murder trial of the social-media age" exemplifies this phenomenon. John Cloud, How the Casey Anthony Murder Case Became the Social-Media Trial of the Century, TIME, June 16, 2011, at 1 (discussing the role of social media in disseminating reliable and frequent information about the Casey Anthony trial to millions via "live streams of the case" and Twitter accounts adding followers "at a rate of hundreds per day"); see also Matthew Mastromauro, Note, Pre-Trial Prejudice 2.0: How YouTube Generated News Coverage Is Set to Complicate the Concepts of Pre-Trial Prejudice Doctrine and Endanger Sixth Amendment Fair Trial Rights, 10 J. HigH TECH. L. 289, 290-91 (2010) ("YouTube, and other video sharing websites cause many changes for the Fourth Amendment right assuring jury purity. YouTube's size and popularity has grown concurrently with the speed and dissemination of the internet itself. First, easier, more affordable, and faster Internet access has allowed YouTube to supplement, and in some places replace, the public's use of traditional news media. Second, unlike traditional news sources, there are no controls or procedures to ensure that the content distributed on websites like YouTube is accurate. Third, content provided on sites like YouTube has outpaced traditional avenues of regulation." (footnotes omitted)).

227. Cf. Mastromauro, supra note 226, at 291 (noting that "unlike traditional news sources, there are no controls or procedures to ensure that the content distributed on websites like YouTube is accurate").

228. James Gobert et al., Jury Selection: The Law, Art and Science of Selecting a Jury $\S 7: 10$, at 291 (3d ed. 2011) ("The modern media age, where news is available in an ever-expanding variety of forms, has exacerbated the problem of pre-trial publicity. On many occasions the Supreme Court has had to address what constitutes an impartial jury, as well as a fair trial, in this context. The results have not always been consistent.").

229. States, of course, are free to develop their own change-of-venue statutes and common law schemes as long as they meet the federal constitutional floor.

230. E.g., Daniels v. Woodford, 428 F.3d 1181, 1211 (9th Cir. 2005) (reversing the district court's denial of the defendant's change-of-venue motion in light of "huge" wave of public passion and fact that eighty-seven percent of jury pool recognized the case from media coverage); Nevers v. Killinger, 990 F. Supp. 844, 855-62 (E.D. Mich. 1997) (failing to transfer venue was manifest error where city of Detroit became convinced that race riots would ensue unless two policemen defendants were found guilty of murdering suspect). Consistent with the observation that the pretrial publicity standard has yielded an incoherent jurisprudence, although the reviewing court in Nevers upheld the district court's grant of habeas relief, it also ruled that the district court erred in applying both the presumed and actual prejudice standards. See Nevers v. Killinger, 169 F.3d 352, 372-74 (6th Cir. 1999), abrogated on other grounds by Harris v. Stovall, 212 F.3d 940, 942-43 (6th Cir. 
venue challenges in federal prosecutions since the Court introduced the totality of the circumstances test in Murphy in 1975.231 In those relatively few cases in which federal defendants have obtained changes of venue at the trial level since Murphy, most were granted either partially or entirely under Federal Rule of Criminal Procedure 21, the federal change-of-venue procedural rule, ${ }^{232}$ which may or may not be coextensive with the federal constitutional standard. ${ }^{233}$

The point regarding federal courts' application of the constitutional change-ofvenue standard is not that federal defendants are rarely granted relief under it, but that federal circuit courts simply do not overturn district court denials of venue challenges. ${ }^{234}$ If one considers the high-profile nature of many federal criminal cases and the fact that federal circuit courts ostensibly review federal district court venue rulings on direct review under a less deferential standard than state court decisions on habeas review, ${ }^{235}$ the fact that federal convictions are not disturbed under the constitutional pretrial publicity standard presents a remarkable, if not inexplicable, track record. It also renders the pretrial publicity standard (or at least its application by federal courts) inherently suspect because it means one of two things. Either federal district courts never commit constitutional error in denying a change of venue, or reviewing courts have vested federal trial courts with so much discretion that the

2000); see also Coleman v. Kemp, 778 F.2d 1487, 1543 (11th Cir. 1985) (holding that the district court's finding that the defendant had not met the burden of demonstrating presumed prejudice was clearly erroneous); Johnson v. Beto, 337 F. Supp. 1371, 1375-77 (S.D. Tex. 1972) (overturning state conviction of AfricanAmerican civil rights leader in Houston who was publicly associated with racial unrest in the city because city wide pressures to convict and punish infected his trial).

231. Successful venue challenges by federal defendants since Murphy in reported and unreported decisions include: United States v. Faulkner, 17 F.3d 745, 757-58 (5th Cir. 1994); Order for Change of Venue at 3-9, United States v. Ressam, No. C99-666C (W.D. Wash. Mar. 3, 2000), ECF No. 56; United States v. Saya, 980 F. Supp. 1157, 1159 (D. Haw. 1997); United States v. McVeigh, 918 F. Supp. 1467, 1470 (W.D. Okla. 1996); United States v. Tokars, 839 F. Supp. 1578, 1580 (N.D. Ga. 1993); United States v. Moody, 762 F. Supp. 1485, 1486 (N.D. Ga. 1991); United States v. Ebens, 654 F. Supp. 144, 144 (E.D. Mich. 1987); United States v. Engleman, 489 F. Supp. 48, 49 (E.D. Mo. 1980); United States v. Abrahams, 466 F. Supp. 552, 558 (D. Mass. 1978); United States v. Maad, 75 Fed. Appx. 599, 601 (9th Cir. 2003).

232. See Saya, 980 F. Supp. at 1158; McVeigh, 918 F. Supp. at 1470; Tokars, 839 F. Supp. at 1580-81; Moody, 762 F. Supp. at 1486, 1490; Ebens, 654 F. Supp. at 146; Engleman, 489 F. Supp. at 49; Abrahams, 453 F. Supp. at $556 \mathrm{n} .12$.

233. See supra notes 140-48 and accompanying text for a discussion of the Murphy Court's evaluation of a defendant's due process rights in the face of sensational media coverage.

234. I am aware of only two federal circuit court reversals of a federal trial court denying a change of venue under the constitutional standard since Murphy. E.g., United States v. Maad, 75 Fed. Appx. 599, 600 (9th Cir. 2003); Isaacs v. Kemp, 778 F.2d 1482, 1483-84 (11th Cir. 1985).

235. See Goss v. Nelson, 439 F.3d 621, 627 (10th Cir. 2006) ("Only when a manifest error occurs can a federal habeas court overturn a state court's finding regarding jury impartiality as a whole. This standard also applies to any questions about the impact of pretrial publicity on the jury pool." (citation omitted) (citing Swindler v. Lockhart, 885 F.2d 1342, 1347 (8th Cir. 1989); Patton v. Yount, 467 U.S. 1025, 1031 (1984))). Change-of-venue decisions under Federal Rule of Criminal Procedure 21 are reviewed for abuse of discretion. E.g., United States v. Campa, 459 F.3d 1121, 1143 (11th Cir. 2006). One would be hard pressed, however, to discern a difference in how courts actually apply the two standards of review since they appear to consistently reach the same results. 
former have abdicated their role in enforcing the constitutional impartial jury right in federal prosecutions.

Perhaps no class of contemporary cases better illustrates the lack of coherence in change-of-venue jurisprudence than those involving the very modern crime of terrorism, where lower courts have reached very different results for similarly situated defendants. The nation's first high-profile domestic terrorism case, United States $v$. McVeigh ${ }^{236}$ decided in 1996, is one of the few successful venue challenges by a federal defendant. ${ }^{237}$ In McVeigh, the district court granted a change of venue based on evidence that the prejudice in Oklahoma, where the crime occurred, was so great that the defendants could not obtain a fair and impartial trial anywhere in the state. ${ }^{238}$ It did not engage in voir dire or otherwise require a showing of actual prejudice. ${ }^{239}$ The district court concluded that a change of venue from Oklahoma was required because of the unique nature of the news coverage in Oklahoma and the impact of the crime on the residents in that venue. ${ }^{240}$ Separate and apart from pretrial publicity, the court noted, potential jurors in that community had experienced an emotional impact unique to that jurisdiction that was sufficient to give rise to a presumption of community-wide bias. $^{241}$

Courts in more recent terrorism cases have reached opposite conclusions under similar facts. In United States v. Lindh, ${ }^{242}$ a case tried on the heels of the September 11 attacks, the district court rejected the notion that personal connections to victims of terrorism in a jurisdiction affected by the attacks were enough to support a presumption of community-wide bias. ${ }^{243}$ In United States v. Awadallah, ${ }^{244}$ a September 11-related prosecution in New York City, the district court denied a change of venue based in part on the observation that "the effects of the September 11 attacks were felt nationwide, and there is no reason to believe that jurors in a different jurisdiction would lack an emotional response with prejudicial effects." ${ }^{245}$ In United States v. Nettles, ${ }^{246}$ the

236. 918 F. Supp. 1467 (W.D. Okla. 1996).

237. McVeigh, 918 F. Supp. at 1470.

238. Id. at 1474 .

239. Id. at 1470 .

240. Id. at 1470-74. The court noted that although the bombing had generated publicity nationwide, the news coverage within Oklahoma remained focused on the bombing and its aftermath for a much longer period of time. Id. at 1471. Such coverage personalized the bombing for Oklahomans to such an extent that for many the only just result would have been a guilty verdict and death sentence. Id. at 1472.

241. Id. at $1472-74$.

242. 212 F. Supp. $2 d 541$ (E.D. Va. 2002).

243. Lindh, 212 F. Supp. 2 d at 550-51 ("[C]ontrary to Lindh's assertions, the fact that a number of the individuals polled in both Virginia and elsewhere knew someone injured or killed in the September 11, 2001 terrorist attacks does not warrant dismissal of the Indictment or a change of venue. Rather, such personal connections to the terrorist attacks are matters adequately addressed and dealt with during the voir dire process.").

244. 457 F. Supp. 2 d 246 (S.D.N.Y. 2006).

245. Awadallah, 457 F. Supp. 2d at 253. In Awadallah, the district court distinguished McVeigh on the ground that Awadallah was not a terrorism case because Awadallah was charged with perjury in conjunction with a grand jury investigation into the attacks. $I d$. at 252 . This distinction seems strained in light of the fact 
Seventh Circuit upheld the denial of a change in venue even though jurors would be hearing the case in the very building the defendant targeted for destruction. ${ }^{247}$

Compounding courts' uneven application of the pretrial prejudice standard is their treatment of the social science evidence that has assumed a prominent, if not indispensable, role in modern change-of-venue litigation. To establish evidence of community prejudice, defendants will often engage experts to conduct public opinion polls, community surveys, focus groups, and mock trials as part of an evidentiary submission. ${ }^{248}$ And, where the motion rests on prejudicial media coverage, the evidentiary submission will include expert testimony providing content analysis of the coverage and about jury psychology. ${ }^{249}$ This social science evidence has assumed such a critical role in change-of-venue litigation that courts will likely consider a motion to change venue that is not supported by social science evidence insufficient to meet the defendant's burden of proof. ${ }^{250}$ Although a trial court may presume prejudice in the community based on this evidence and change venue without questioning prospective jurors, the most common practice is to defer ruling until after voir dire, on the theory that the trial court will be able to detect and contain or eliminate juror bias through that process. ${ }^{251}$

The effect of pretrial publicity on juror impartiality and the tools trial courts employ to identify and eliminate it have been the subject of a significant amount of social science research. That research has provided a trove of valuable insights into the sources and effects of bias in the jury trial process and the ability of the legal system to

that the perjury charges were directly related to Awadallah's knowledge of facts of the attacks and in light of the prosecutor's references to September 11 in closing argument. Id. at $253 \mathrm{n} .53$ (noting that the "[g]overnment's closing argument . . . began and ended with an appeal to recall that this case involved 'the worst terrorist attacks in ... our ... nation's history"').

246. 476 F.3d 508 (7th Cir. 2007).

247. Nettles, 476 F.3d at 514-15 (noting that although jurors' impartiality might be impacted by this fact, there was no basis to find juror bias because the attempted crime had failed and "had a zero percent chance of success").

248. E.g., United States v. McVeigh, 918 F. Supp. 1467, 1471 (W.D. Okla. 1996) (relying heavily on the testimony of an expert in news media analysis).

249. Establishing actual prejudice requires that the party moving for a change in venue demonstrate that jurors in the district possess a partiality or hostility that cannot be set aside. In this context, the results of public opinion polls, pre-trial community surveys, focus groups, and mock trials, as well as affidavits of members of the community, may all be of evidentiary value. Where there has been extensive and prejudicial pre-trial media coverage, a content analysis of the reporting can be prepared by a jury consultant or media analyst to support the motion for a change in venue.

GOBERT ET AL., supra note 228, § 2:4, at 64 (footnote omitted).

250. See United States v. Lindh, 212 F. Supp. 2d 541, 550-51 (E.D. Va. 2002) (describing the results of studies which tested public opinion and media coverage in a wide variety of national markets); State v. Erickstad, 2000 ND 202, ๆ 9, 620 N.W.2d 136, 140 ("Mere quantity of media coverage is not the focus; rather, the defendants must show there was improperly prejudicial publicity which would have caused such bias against them that it would have been impossible to select a fair and impartial jury" using, for example, "qualified public opinion surveys, other opinion testimony, or any other evidence demonstrating community bias caused by the media coverage.").

251. See United States v. Haldeman, 559 F.2d 31, 62-64 (D.C. Cir. 1976). 
address it. It also appears to have produced a high level of consensus about the basic social science principles implicated in change-of-venue motions. As a threshold matter, for example, many studies show that exposure to pretrial publicity can affect prospective jurors' views of a case. ${ }^{252}$ Further, pretrial publicity that has emotional (rather than factual) content can have a significant impact on jurors' willingness to convict a defendant. ${ }^{253}$ Despite trial courts' widespread willingness to accept a juror's statement that he or she will be fair notwithstanding exposure to extraneous prejudicial information, such self-assessments are highly unreliable. ${ }^{254}$ And despite trial courts' confidence that juror bias can be detected and eliminated through searching and careful voir dire, it cannot, ${ }^{255}$ a problem compounded in federal court, where it is more common for the judge, rather than counsel, to conduct voir dire. ${ }^{256}$ According to social science, the least effective means of eliminating jury bias is through deliberations and instructions to the jury. ${ }^{257}$ And the single most effective remedy, according to social science, is the one the law employs with the least frequency-selecting a jury from

252. See Neil Vidmar, When All of Us Are Victims: Juror Prejudice and "Terrorist" Trials, 78 CHI.KeNT L. REv. 1143, 1150-51, 1150 n.48 (2003) (describing a range of manifestations including "initial assumptions about a defendant's guilt," and "influence[ing] predeliberation preferences of verdicts," among other impacts).

253. See Geoffrey P. Kramer et. al., Pretrial Publicity, Judicial Remedies, and Jury Bias, 14 LAW \& Human BeHAV. 409, 411-14 (1990) (explaining how jurors exposed to "emotional" pretrial publicity (i.e., "graphic or lurid depiction[s]" of a victim's injuries) as opposed to strictly "factual" publicity will be more likely to convict and be more passionate about their stance).

254. See Studebaker \& Penrod, supra note 225, at 434-35 (describing results of study showing that "well-informed" jurors who later return a guilty verdict are also highly likely to assert impartiality).

255. See Dale W. Broeder, Voir Dire Examinations: An Empirical Study, 38 S. CAL. L. Rev. 503, 528 (1965) (concluding that voir dire is grossly ineffective in screening juror bias, that jurors consciously or unconsciously lie on voir dire, and that voir dire is more effective as a forum for indoctrination than as a means of deselecting unfavorable jurors); see also Norbert L. Kerr et al., On the Effectiveness of Voir Dire in Criminal Cases with Prejudicial Pretrial Publicity: An Empirical Study, 40 AM. U. L. Rev. 665, 695-99 (1991) (concluding that the results of a study show that voir dire is not an effective barrier against juror bias created by exposure to pretrial publicity).

256. See Mark W. Bennett, Unraveling the Gordian Knot of Implicit Bias in Jury Selection: The Problems of Judge-Dominated Voir Dire, the Failed Promise of Batson, and Proposed Solutions, 4 Harv. L. \& POL'Y REV. 149, 160 (2010) (suggesting that the questions judges typically ask during voir dire "do[] not begin to address implicit bias, which by its nature is not consciously known to the prospective juror[, and that] empirical research suggests that potential jurors respond more candidly and are less likely to give socially desirable answers to questions from lawyers than from judges"); see also Vidmar, supra note 252, at $1171 \mathrm{n} .88$ (compiling and discussing research findings suggesting that "judge-conducted voir dire is less likely to produce full disclosure in jurors than lawyer-conducted voir dire"); Mary R. Rose \& Shari Seidman Diamond, Judging Bias: Juror Confidence and Judicial Rulings on Challenges for Cause, 42 LAW \& SoC'Y REv. 513, 517-18 (2008) (noting research suggesting "that even though judges have the discretion to overrule the juror's self-assessment, they are loathe to do so" and that "far from neglecting self-reports, some judges appear to take an active role in shaping answers so that they conform to an image of neutrality" and "declare jurors to be fair when jurors say they can be fair").

257. See Kramer et al., supra note 253 , at 430 (noting admonitions to ignore all publicity have no effects on jurors, and can actually increase the impact of factual publicity); Norbert L. Kerr, The Effects of Pretrial Publicity on Jurors, 78 JUdiCATURE 120, 127 (1994) (explaining how the research demonstrates that jury instructions are not helpful in preventing jury bias, and may even make things worse). 
outside the community by either changing venue or changing the venire. ${ }^{258}$

The disconnect between the outcomes social science would dictate, and what courts actually do in evaluating juror bias in venue challenges, suggests a few possibilities. One explanation is that courts are not sufficiently familiar or comfortable with the relevant social science to fully apply or benefit from it. ${ }^{259}$ Another possibility is that factors other than jury bias play an unconscious and unacknowledged role in the resolution of change-of-venue motions-factors such as judges' individual interests and courts' institutional considerations, or judicial antipathy towards social science. ${ }^{260}$ For example, judges may resist changing venue because doing so is an admission that a defendant can only receive a fair trial in another jurisdiction or a change of venue may undermine a community's interest in seeing justice done where the crime was committed. ${ }^{261}$ Furthermore, venue changes, particularly in federal court, are extremely costly and highly inefficient; if the trial judge moves with the transferred case, he or she may be unwilling to incur the personal inconvenience of a lengthy absence from home and chambers. ${ }^{262}$ In any case, it is clear that the law has declined to embrace social science's understanding about juror bias and its teaching about whether and how such bias can be detected and eliminated.

A major concern with allowing trial courts such unfettered discretion in this area is that change-of-venue decisions can turn on the proclivities and inclinations of individual trial judges. ${ }^{263}$ For example, it is undeniable that granting a change of venue

258. See Kramer et al., supra note 253, at 435 (arguing that change of venue and change of venire are most effective remedies and courts would be well-advised to use change of venue and change of venire despite high costs involved).

259. This is a very unlikely explanation given the amount of social science evidence that is routinely presented to trial courts in support of change-of-venue motions. E.g., United States v. McVeigh, 918 F. Supp. 1467, 1471 (W.D. Okla. 1996) (describing in detail the analysis of a news media expert who testified for the defense in support of a motion to change venue).

260. The mischief presented by an ill-defined standard is that it allows the personal predilections and inclinations of even the best-intentioned judges to assume an unspoken and unchecked role in jury selection and change-of-venue determinations. Simple human nature may be the most powerful and the most prevalent. For example, a judge may be reluctant to dismiss a juror for bias because it is tantamount to a public statement that the court does not believe that juror can be fair. See Rose \& Diamond, supra note 256, at 539 (explaining how during voir dire judges develop a social relationship with jurors and that there is "awkwardness" in overruling a juror). For a comprehensive analysis of the law's discomfort with, if not outright hostility towards, social science, see J. Alexander Tanford, The Limits of a Scientific Jurisprudence: The Supreme Court and Psychology, 66 IND. L.J. 137, 152-57 (1990) (reviewing six theories regarding the rationale for courts' reluctance to rely on empirical research).

261. See Note, Community Hostility and the Right to an Impartial Jury, 60 ColuM. L. REV. 349,376 (1960) (exploring the significant considerations against granting a change of venue, such as the negative attitude of the community towards the legal process should it be granted); see also GOBERT ET AL., supra note $228, \S 2: 4$, at 66 n.24 (" $[\mathrm{H}]$ aving invested considerable time in attempting to empanel an impartial jury, a judge may become psychologically disinclined to order a change in venue, which might be regarded as reflecting adversely on the decision to conduct voir dire without ruling on the original motion.").

262. Cf. McVeigh, 918 F. Supp. at 1474 (transferring the case from the charging venue to the judge's home venue).

263. See Vineet R. Shahani, Note, Change the Motion, Not the Venue: A Critical Look at the Change of Venue Motion, 42 AM. CRIM. L. REV. 93, 103-04 (2005) (exploring scholars' criticism of the general 
entails significant personal and institutional costs and inconveniences for trial courts. ${ }^{264}$ Further, declaring a failed voir dire in the charging venue and starting the entire process again in another jurisdiction not only delays the defendant's trial, it also impacts the court's docket and budget. Because these are real and significant disincentives to granting a change of venue, it is not inconceivable that they may unconsciously influence an individual judge's willingness to incur these burdens. Virtually unlimited discretion in this area, consequently, almost ensures that questions of judicial economy and convenience can play a significant role in change-of-venue decisions, and it creates a genuine risk that trial courts will equate an impartial jury with one that can be provided at minimal cost and disruption to the court. ${ }^{265}$

Not surprisingly, given the expense and inconvenience associated with moving a trial, changes of venue are rarely granted. ${ }^{266}$ Some commentators cite to the "exacting" nature of the constitutional standard to explain why changes in venue are so rare. ${ }^{267}$ While the pretrial publicity standard does set a high bar for securing a change of venue by placing the burden on the defendant to show bias, as coverage of high-profile criminal cases has become more sensational, more pervasive, more accessible, and less accountable, even an exacting pretrial publicity standard should yield more, not fewer, successful venue challenges. But this has not been the case. ${ }^{268}$ Thus, pointing to the demanding requirements of the pretrial publicity standard does not provide a complete

effectiveness of appellate courts in their presumption "that trial courts assume significant discretion in determining the impartiality of juries and in creating remedial measures," an approach which "fails to encourage proactive judicial administration or the creation of concrete guidelines to assess pretrial publicity").

264. E.g., United States v. Skilling, 554 F.3d 529 (5th Cir. 2009) (lasting four months); cf. Hayes v. Ayers, 632 F.3d 500, 525 n.1 (9th Cir. 2011) (Fletcher, J., dissenting) (arguing that the trial judge had considered the costs to the court to be the most important factor in ruling upon a motion for change of venue).

265. See Hayes, 632 F.3d at 525 n.1 (Fletcher, J., dissenting) (criticizing how "[t]he trial judge blatantly and openly considered costs and other political issues in ruling upon the motion for change of venue" and alleging that "[i]n the face of overwhelming evidence indicating that the jury was tainted by previous media exposure, he considered costs to the court to be more important"). Notably, in United States v. McVeigh, one of the few recent federal cases in which a federal defendant was granted a change of venue, the judge who granted the change of venue was not from the charging venue and he transferred the case to the venue in which his chambers were located. 918 F. Supp. at 1474. Judge Matsch sat by designation after all the federal judges in the District of Oklahoma recused themselves - and he transferred venue to Denver, in the District of Colorado, his home venue. $I d$. Thus, not only did the judge avoid the inconvenience of presiding over a lengthy trial far from home, he eliminated any personal inconvenience by moving the trial to Denver.

266. See Laurie L. Levenson, Change of Venue and the Role of the Criminal Jury, 66 S. CAL. L. REV. 1533, 1539 n.27 (1993) (asserting that change of venue is extremely rare, especially in large venues with diverse jury pools); Michael Jacob Whellan, Note, What's Happened to Due Process Among the States? Pretrial Publicity and Motions for Change of Venue in Criminal Proceedings, 17 AM. J. CRIM. L. 175, 183-84 (1990) (noting that courts in some states will not approve a change in venue absent a showing of a biased jury or an occasion where fair trial is impossible).

267. See, e.g., 2 Charles Alan Wright et Al., Federal Practice and Procedure $§ 343$ (4th ed. 2012) (explaining how "with the standard on such motions so exacting it is not surprising that in the great bulk of cases relief has been denied").

268. See Whellan, supra note 266, at 176, 179 (noting that although the media now rapidly provides information throughout a community and provides extensive coverage of major trials, many judges still believe they should rarely grant changes in venue). 
or satisfactory explanation of why successful venue challenges on constitutional grounds have become virtually nonexistent in the Internet age.

The practical issue for defendants, practitioners, and judges is that after decades of pretrial publicity jurisprudence, the law has been unable to definitively identify what it means to be a constitutionally impartial jury in high-profile cases. ${ }^{269}$ Put another way, courts have been unable, after decades of examining the issue, to figure out how to ascertain, as a constitutional matter, when the law can declare that a jury verdict in a high-profile case was based only on the evidence produced against a defendant in court. The failure to articulate a coherent standard of impartiality has sent countless defendants in high-publicity cases in search of sufficient evidence to invoke a presumption of jury bias, which may no longer exist under a nebulous, easily manipulated, and ill-defined constitutional test. ${ }^{270}$ Indeed, one of the few things that can be said with confidence in this area of law is that trial courts rarely grant a change of venue on constitutional grounds, and appellate courts rarely reverse trial court venue decisions, but that defendants cannot get serious consideration of a venue challenge without relying on extensive social science evidence, which is extremely expensive to prepare and present. ${ }^{271}$ This sets up a zero-sum game for defendants and their attorneys - although venue changes under the pretrial publicity standard may be a foregone conclusion resting entirely on the trial court's unchecked discretion, defense counsel would likely be remiss (if not constitutionally ineffective) in counseling defendants in high-profile cases to forgo a motion to change venue. The net result is tremendous expenditure of resources for defendants, prosecutors, and trial courts and a significant pretrial delay while a change-of-venue motion is prepared and litigated in what more often than not turns out to be a futile venture.

269. See Gobert ET AL., supra note 228, § 2:9, at 77 (explaining that the challenge is to define impartiality in a way that is acceptable in a legal context, while not ignoring the moral, political, economic, and psychological baggage that prospective jurors invariably bring with them); Newton N. Minow \& Fred H. Cate, Who is an Impartial Juror in an Age of Mass Media?, 40 AM. U. L. REV. 631, 646 (1991) (explaining how "irrespective of more than a century of Supreme Court guidance on the issue, there appears to be little consensus on what an impartial jury really is").

270. Cf. Minow \& Cate, supra note 269, at 662 n.195 (stating that "countless litigants" will be denied their right to a fair trial absent a change in the standard for change of venue due to pretrial publicity); Whellan, supra note 266, at 180 (outlining the difficulty that defendants face in jurisdictions that require them to meet a presumption of prejudice standard, such as the requirement to show through voir dire that pretrial publicity has created such prejudice that a change of venue is necessary in to obtain a fair trial). See generally Hardaway \& Tumminello, supra note 218.

271. See supra notes $252-58$ for examples of relevant social science studies. Though courts may be to be hostile to social science evidence, at least in federal court, such social science evidence is routinely submitted in support of change-of-venue motions because trial courts have come to expect this type of evidence in support of change-of-venue motions in high-profile cases. See, e.g., United States v. Grace, 408 F. Supp. 2d 998, 1001 (D. Mont. 2005) (listing the materials provided by the defendants which included expert reports analyzing pretrial publicity); United States v. McVeigh, 918 F. Supp. 1467, 1471 (W.D. Okla. 1996) (stating that an expert in news media analysis testified for the defense); see also Tanford, supra note 260 at 144-50 (discussing the Supreme Court's hostility to social science). 


\section{E. Skilling and What it Left Unanswered}

Against this backdrop, the Supreme Court accepted certiorari in Skilling v. United States in 2009.272 Skilling was the first venue challenge the Court took up since it decided Mu'Min in 1991. It is also one of the only times the Court has considered a modern pretrial publicity venue challenge on direct appeal of a federal convictionmost of the Court's previous pretrial publicity cases arose on habeas review. ${ }^{273}$ The Court's decision to grant certiorari in Skilling led some observers to anticipate a change or refinement in the pretrial publicity change-of-venue standard, given the discord in the law outlined above and the significant changes in the nature and reach of pretrial publicity since the Court considered the issue almost two decades earlier in Mu' Min. $^{274}$ The Court, however, disappointed any hopes for a watershed opinion in federal changeof-venue law that would address some unresolved questions in its jurisprudence. ${ }^{275}$ Instead, the Court issued a six-three opinion in which the majority and dissenting Justices did little more than apply the existing legal standard to undisputed facts and reach different conclusions as to whether Skilling's right to an impartial jury had been violated $^{276}$ — essentially mirroring lower courts' varying and inconsistent applications of the standard.

The massive corporate fraud perpetrated by Jeffery Skilling and his codefendants at Enron is familiar to any contemporary legal audience; thus, only the background necessary to a discussion of the change-of-venue issue is set forth here. Enron was a Houston-based energy company founded in 1985 that eventually became the seventh highest revenue-grossing company in the United States and one of the world's largest energy companies. ${ }^{277}$ Enron filed for bankruptcy in December 2001 and, at the time, it

272. 130 S. Ct. 393 (2009) (mem.).

273. See supra Part III.B for a discussion of Supreme Court cases decided on habeas review and state postconviction review.

274. See, e.g., Farmer, supra note 16, at 7 (noting that Skilling provided an opportunity for the Supreme Court to alter the presumption giving discretion to the trial court by "address[ing] definitively whether it is even realistic or practical to conduct voir dire after a finding of presumed prejudice of the entire community in which the case is to be tried").

275. Since the opinion added little to existing jurisprudence except more confusion, one can only speculate why the Court bothered to take the change-of-venue issue in Skilling in the first place. After the Court accepted certiorari in Skilling, one commentator observed that the case

$[\mathrm{P}] \mathrm{resents} \mathrm{two} \mathrm{related} \mathrm{tantalizing} \mathrm{questions:} \mathrm{why} \mathrm{did} \mathrm{the} \mathrm{Supreme} \mathrm{Court} \mathrm{agree} \mathrm{to} \mathrm{consider} \mathrm{the} \mathrm{issue}$ of juror prejudice, and, given that they did so agree, how will they treat the issue? ....

$\ldots$

Since the Supreme Court is not usually an error-correcting court, it may have accepted this issue for a more sweeping pronouncement of how prejudicial pretrial publicity cases are handled in the future.

Farmer, supra note 16, at 9. As it turns out, the Court did none of this.

276. Skilling v. United States, 130 S. Ct. 2896, 2916-17 (2010) (majority opinion); id. at 2949-54, (Sotomayor, J., concurring in part and dissenting in part). Both the majority and dissenting opinions relied on Rideau, Estes, Sheppard, Murphy, and Yount to support their opposing views about whether pretrial publicity unconstitutionally affected the jury deciding the case.

277. Skilling, 130 S. Ct. at 2907. 
was the largest bankruptcy in US history. ${ }^{278}$ After the bankruptcy, Enron's stock became worthless. ${ }^{279}$ The bankruptcy cost four thousand employees their jobs, and many of them their life savings, when their retirement accounts evaporated and investors lost billions of dollars. ${ }^{20}$ Enron's demise affected the entire Houston-area economy- - [a]ccounting firms that serviced Enron's books had less work, hotels had more open rooms, [and] restaurants sold fewer meals." ${ }^{281}$ Skilling joined Enron in 1990 and rose through the corporate ranks, becoming Enron's President and Chief Operating Officer in 1997 and the Chief Executive Officer in February, 2001. ${ }^{282}$ Skilling resigned from Enron on August 14, 2001, just months before Enron filed for bankruptcy. ${ }^{283}$

An investigation into Enron revealed an extensive and intricate scheme perpetrated by Skilling and other Enron executives to deceive investors about the state of Enron's finances by overstating the company's financial health to keep Enron's short-run stock price artificially high. ${ }^{284}$ In 2004, the government charged Skilling, Kenneth Lay, ${ }^{285}$ and one other executive ${ }^{286}$ in the Southern District of Texas, located in Houston, with offenses relating to the conspiracy to manipulate Enron's earnings. Not surprisingly, given the magnitude and audacity of the Enron crimes, the importance of Enron to the local economy, and the attendant wide-scale consequences of its collapse, the Enron matter was covered extensively in the media. ${ }^{287}$ Asserting that an impartial jury could not be seated in Houston due to prejudicial pretrial publicity and community hostility, Skilling moved for a change of venue before the start of his jury trial. ${ }^{288}$ The trial court denied the motion and the case went to trial in $2006 .{ }^{289}$ Following a four-

278. Shaheen Pasha \& Jessica Seid, Lay and Skilling's Day of Reckoning, CNN MONEY (May 25, 2006, 7:35 PM), http://money.cnn.com/2006/05/25/news/newsmakers/enron_verdict/index.htm.

279. Enron's stock "traded at $\$ 90$ per share in August 2000 [and] plummeted to pennies per share in late 2001." Skilling, 130 S. Ct. at 2907.

280. Pasha \& Seid, supra note 278; see also United States v. Skilling, 554 F.3d 529, 560 (5th Cir. 2009) (describing how "[t]housands of Enron employees in Houston lost their jobs, and many saw their 401(k) accounts wiped out"), aff'd in part, vacated in part, 130 S. Ct. 2896 (2010).

281. Skilling, 554 F.3d at 560 .

282. Skilling, 130 S. Ct. at 2907.

283. Id.

284. Id. at 2908 .

285. Lay recruited Skilling to Enron and served as Chief Executive Officer before Skilling came to Enron and after Skilling left. Id. at 2907; Skilling, 554 F.3d at 534.

286. Other Enron executives involved in the conspiracy included Chief Accounting Officer Richard Causey, Chief Financial Officer Andrew Fastow, and Treasurer Ben Glisan. Skilling, 130 S. Ct. at 2907; Skilling, 554 F.3d at 534. Skilling, Lay, and Causey were charged with conspiracy to commit securities and wire fraud and with more than " 25 substantive counts of securities fraud, wire fraud, making false representations to Enron's auditors, and insider trading." Skilling, 130 S. Ct. at 2908. Causey pleaded guilty three weeks before trial and Lay was convicted, but died before he was sentenced, and his conviction was vacated leaving Skilling as the only defendant on review. Skilling, 554 F.3d at 542 \& n.9.

287. See Skilling, 554 F.3d at 559-60, 559 n.41 (describing an "immense" volume of inflammatory pretrial material and noting that there were "thousands of relevant local television features and hundreds of newspaper articles" about Skilling and Enron and the coverage continued throughout the pretrial period).

288. Skilling, 130 S. Ct. at 2908.

289. Id. at 2908-10. 
month trial, Skilling was convicted of fraud and acquitted of some insider-trading counts; he was eventually sentenced to over twenty-four years imprisonment and ordered to pay $\$ 45$ million in restitution. ${ }^{290}$

In denying the change-of-venue motion, the district court concluded that the media coverage was insufficient to give rise to a presumption of prejudice and that it would be able to uncover any jury bias during voir dire. ${ }^{291}$ And, as is invariably the case, based on voir dire, the district court concluded that it would be able to seat an impartial jury in Houston. ${ }^{292}$ On appeal, the Fifth Circuit affirmed, noting with a bit of understatement that "[i]t would not have been imprudent for the court to have granted Skilling's transfer motion." 293 Significantly, although the Fifth Circuit upheld the district court, it held that the lower court erred in concluding that the pretrial publicity record was insufficient to give rise to a presumption of prejudice and it faulted the district court for "overlook[ing] that the prejudice [in the case] came from more than just pretrial media publicity, but also from the sheer number of victims." 294 Citing the district court's "exemplary" voir dire, however, the Fifth Circuit concluded that the government had rebutted the presumption of prejudice because the voir dire record established that no juror who was actually biased sat on Skilling's jury. ${ }^{295}$

The Supreme Court, in a fractured opinion, agreed that Skilling was tried by an impartial jury, but on different grounds than the Fifth Circuit. ${ }^{296}$ The Court disagreed with the Fifth Circuit that the evidence of pretrial publicity and community hostility was sufficient to raise a presumption of prejudice, but a five-Justice majority agreed with the Fifth Circuit that the voir dire record established no actual prejudice. ${ }^{297}$ Justice Alito concurred with the majority's result, but stated that he would abandon the presumed prejudice standard altogether. ${ }^{298}$ Three Justices dissented; they agreed with the majority that the record did not require a presumption of community prejudice, but they considered the district court's five-hour voir dire to be too perfunctory to identify juror bias in light of the extreme community prejudice surrounding Skilling's trial. ${ }^{299}$ Thus, from trial through direct review, Skilling produced five different opinions from thirteen different jurists who could agree neither on the law nor its proper application to the facts before them-they disagreed (1) whether the Court should recognize a presumption of prejudice, (2) what the contours of the pretrial publicity standard are,

290. Id. at 2911

291. Id. at 2900 .

292. Id. at 2901

293. United States v. Skilling, 554 F.3d 529, 558 (5th Cir. 2009), aff'd in part, vacated in part, $130 \mathrm{~S}$. Ct. 2896 (2010).

294. Id. at 560.

295. Id. at 562-65.

296. Skilling, 130 S. Ct. at 2925 (holding that Skilling failed to establish that a presumption of prejudice arose, in contrast to the Fifth Circuit holding that Skilling established a presumption of prejudice, but the government successfully overcame this rebuttable presumption).

297. Id.

298. Id. at 2941 (Alito, J., concurring).

299. Id. at 2952, 2958 \& n. 17 (Sotomayor, J., concurring in part and dissenting in part). 
(3) what evidence is sufficient to establish a presumption of prejudice, (4) whether the presumption is rebuttable, (5) what type of evidence elicited during voir dire constitutes proof of actual bias, and (6) how thorough voir dire needs to be in a high-publicity case to warrant deference to a trial court's bias determinations. ${ }^{300}$

The Skilling majority rejected his claim that the content and volume of pretrial publicity attending his case gave rise to a presumption of prejudice in Houston after relying on a number of factors under the totality of the circumstances test ${ }^{301}$ : (1) Houston's size — a city with 4.5 million individuals "eligible for jury duty," (2) the absence of a confession or "other blatantly prejudicial information" in local media reports, (3) the fact that four years elapsed between the Enron's bankruptcy and Skilling's criminal trial, and (4) Skilling's acquittal on some counts with which he was charged. ${ }^{302}$ The majority found that "[a]lthough the widespread community impact necessitated careful identification and inspection of prospective jurors' connections to Enron, the extensive screening questionnaire and follow-up voir dire were well suited to that task. And hindsight shows the efficacy of these devices; . . . jurors' links to Enron were either nonexistent or attenuated." 303 A presumption of prejudice the Court stated "attends only the extreme case[,]" which it described as proceedings that entirely lack "the solemnity and sobriety to which a defendant is entitled in a system that subscribes to any notion of fairness and rejects the verdict of a mob." 304

Issues the Skilling Court could have addressed, but did not, include whether a defendant can ever satisfy the presumed prejudice standard without a showing that his or her trial was accompanied by the type of "circus atmosphere" and televised confession described in Rideau and Sheppard, and whether presumed jury prejudice is ever rebuttable, even though the Fifth Circuit specifically so held. ${ }^{305}$ Justice Alito, in

300. Perhaps the most irrefutable proof that the federal change-of-venue standard has produced an unintelligible, inconsistent, and unpredictable jurisprudence is the fact that Skilling produced so many different interpretations of the facts under a settled constitutional standard. An interesting side note in Skilling is the relationship between the lineup of the Justices and their trial court experience - as one of Skilling's attorneys noted:

It is disconcerting to see the majority working so hard to demonstrate that the prudent course - a venue transfer - was not the better choice, especially when the only justice who has experience both as a district judge and with voir dire in high-profile cases [Justice Sotomayor] is pointing out just how wrong things went in Mr. Skilling's trial.

Tony Mauro, In 4 Key Rulings, Supreme Court Limits Fraud Statutes' Reach, NAT'L L.J. (June 25, 2010), http://www.law.com/jsp/article.jsp?id=1202462988905\&slreturn=1 (quoting Jeffrey Green, Partner, Sidley Austin).

301. See Skilling, $130 \mathrm{~S}$. Ct at 2925 (noting that the Court delivers its opinion after "[t]aking account of the full record").

302. Id. at 2915-16. The majority commented "[i]t would be odd for an appellate court to presume prejudice in a case in which jurors' actions run counter to that presumption[,]" id. at 2916, a premise squarely rejected by the dissent. $I d$. at 2963 (Sotomayor, J., concurring in part and dissenting in part) (offering that the juries' actions in acquitting Skilling on some charges may be reflective of the prosecution failing to emphasize these charges at trial).

303. Id. at 2917 (majority opinion).

304. Id. at 2914-15, 2915 n.12 (citing Murphy v. Florida, 421 U.S. 794, 798-99 (1975)).

305. Id. at $2917 \mathrm{n} .18$ (declining to address whether a presumption of prejudice can be rebutted and, if so, 
his concurring opinion, opined that a presumption of prejudice under the standard can be rebutted by the prosecution through reliance on jurors' voir dire testimony, but this issue was not directly taken up by the majority. ${ }^{306}$ The Court also declined to address whether the change-of-venue standard under Federal Rule 21 is coextensive with the constitutional standard that has evolved mostly within the context of postconviction review, or whether challenges brought by federal defendants on direct review should be subject to a less deferential standard than that used to review state court decisions. ${ }^{307}$ Finally, although the genesis of the pretrial publicity standard was a deep concern with the constitutional balance between fair trials and free press, the Skilling majority contains no discussion of press freedoms or the revolution in mass communications that has occurred since its last change-of-venue opinion in 1991.

The totality of the circumstances analysis notwithstanding, it is hard to conceive of a more compelling set of facts in support of a change of venue based on pretrial publicity than those presented in Skilling-if a change of venue was not constitutionally required on that record, it is fair to ask whether any set of facts exists that requires a change of venue based on pretrial press coverage. ${ }^{308}$ It is noteworthy that the entire local United States Attorney's Office recused itself from the Government's

what standard of proof governs the question of rebuttal). The ABA takes the position that a defendant does not need to establish actual prejudice to secure a venue change. See 2 AMERICAN BAR ASSOCIATION, STANDARDS FOR CRIMinal Justice, § 8-3.3(c) (2d ed. Supp. 1982) (clarifying that the determination shall be based on public opinion surveys, individual opinions, "or a court's own evaluation of the nature, frequency, and timing of the material involved"). But see United States v. Campa, 459 F.3d 1121, 1143 (11th Cir. 2006) (en banc) (explaining that presumption of bias is rebuttable by prosecution which may demonstrate the impartiality of the jury by reliance on voir dire testimony), Coleman v. Kemp, 778 F.2d 1487, 1541 n.25 (11th Cir. 1985) ("We do not read Rideau to imply that the voir dire cannot rebut a presumption of prejudice. . . It might be argued that the threshold showing required to presume prejudice is so high that any rebuttal is inconceivable. However, without expressly deciding the issue, we decline to read Rideau in this fashion, and we assume that there can be such a rebuttal." (citation omitted)); United States v. Chagra, 669 F.2d 241, 250 (5th Cir. 1982) (stating that presumption of prejudice "is rebuttable ... and the government may demonstrate from the voir dire that an impartial jury was actually impaneled in appellant's case" and "[i]f the government succeeds in doing so, the conviction will stand despite appellant's showing of adverse pretrial publicity" (citations omitted)), partially overruled by Garrett v. United States, 471 U.S. 773 (1985).

306. Skilling, 130 S. Ct. at 2941 (Alito, J., concurring). Justice Sotomayor also noted the majority's apparent acceptance of a presumption that can be rebutted.

The Court of Appeals incorporated the concept of presumptive prejudice into a burden-shifting framework: Once the defendant musters sufficient evidence of community hostility, the onus shifts to the Government to prove the impartiality of the jury. The majority similarly envisions a fixed point at which public passions become so intense that prejudice to a defendant's fair-trial rights must be presumed. The majority declines, however, to decide whether the presumption is rebuttable, as the Court of Appeals held.

Id. at 2948 (Sotomayor, J., concurring in part and dissenting in part). But see Craig M. Bradley, Skilling II: An Unbiased Jury?, 47 TRIAL 50, 51 (2011) ("Unlike the Fifth Circuit, the Court seemed to treat the presumption of prejudice as a mandatory, rather than rebuttable, presumption but found that it should be applied only in rare cases.").

307. Skilling, 130 S. Ct. at 2913 n.11.

308. That is, any set of facts falling short of a media-infused breakdown in the solemnity of the judicial proceedings such as occurred in Sheppard v. Maxwell, Estes v. Texas, and Rideau v. Louisiana. 
investigation into Enron's collapse because of the company's extensive ties to the community. ${ }^{309}$ This fact alone speaks volumes about the widespread impact Enron's crimes had on the community and the residents of the Houston area. Further, written questionnaires distributed to Skilling's potential jurors revealed that more than a third were victims of Enron's collapse or knew someone who was. ${ }^{310}$ The community-wide impact of the Enron crimes was further reflected in the voir dire record, which established that five of Skilling's seated jurors and alternates had some connection to a friend or colleague who had been affected by Enron's collapse. ${ }^{311}$ Even if one disagrees that the volume and content of the pretrial publicity that accompanied Skilling's case was unprecedented, at the very least, the case presented an extraordinarily close call (as the various opinions attest).

Skilling's impact, thus, was to further limit the Court's early pretrial publicity cases strictly to their facts and to leave this area of law to continue "developing" on a case-by-case basis. To the extent there was any doubt on this point, Skilling also confirmed that reviewing courts will continue to accord extreme deference to trial courts' assessment of jury bias, a deference that, in practice, allows individual judges to develop and impose a standard of jury impartiality informed by their own norms, values, and interests, completely unchecked by any meaningful appellate review. Following Skilling, it appears extremely unlikely any trial court denial of a change of venue will ever be overturned under the existing constitutional pretrial publicity standard absent a showing that the defendant was tried by a kangaroo court in a small, rural jurisdiction shortly after his or her confession or other highly damaging information was widely disseminated in the charging venue. ${ }^{312}$ However, because the Court left significant questions of law open concerning the viability, scope, and operation of the presumed prejudice standard, defendants and their lawyers must continue to press constitutional change-of-venue motions since, at least in theory, the possibility of obtaining a change of venue based on pretrial publicity continues to exist. And because Skilling has raised the bar so high that it has likely eliminated any possibility of a successful posttrial challenge to a denial of a change of venue on constitutional grounds - such a venue challenge must be won pretrial or not at all.

\section{The COMmon LAW CASE For RECOGNIZING IMPlied COMMUNity Bias IN CASES INVOLVING CATASTROPHIC LOCAL HARM}

The Court's original pretrial publicity and change-of-venue jurisprudence arose in the context of rapid changes in the nature, reach, and format of Americans' sources of information and news, which included the ascendency of the visual medium of

309. Skilling, 130 S. Ct. at 2942 (Sotomayor, J., concurring in part and dissenting in part).

310. Id. at 2960 n. 21.

311. Id.

312. If a finding of prejudice hinges on the actual conduct of trial proceedings, rather than pretrial events, furthermore, it is axiomatic that the former will never be capable of pretrial proof since it is based on events during, not before, the trial. Such events will necessarily be reviewed post trial and in hindsight, thus further eviscerating the notion of a prophylactic constitutional standard to be implemented pretrial. 
television as the primary source of news for most Americans. ${ }^{313}$ One of the results of the increasing reach of the media was that more jurors would be exposed to coverage of crimes and related proceedings. ${ }^{314}$ The question, as originally framed by the courts in this context, was how to accommodate both the constitutional impartial jury and free press guarantees in light of these developments. ${ }^{315}$ One option would have been to emulate the English model and craft a remedy limiting the information that could reach potential jurors to protect defendants' impartial jury rights. ${ }^{316}$ Such a remedy, however, would necessarily require restricting freedom of press, a step the Court elected not to take. $^{317}$ Instead, the Court put the onus on trial courts to move or continue trial proceedings when prejudicial pretrial publicity threatens to impair a defendant's impartial jury right. ${ }^{318}$

At least early in its jurisprudence, the Court (and lower courts following its lead) embraced the notion that prejudicial pretrial publicity and community hostility could so affect a jury pool in a charging venue that it may be impossible to draw a constitutionally impartial jury in that location; where that is the case, a change of venue is the only constitutionally acceptable remedy. ${ }^{319}$ Although the Court has not overturned a single conviction on presumed prejudice grounds since Rideau, it has consistently recognized at least the possibility of presumed prejudice as a ground for a change of venue, no matter how remote the possibility of establishing such prejudice may be. ${ }^{320}$ The change-of-venue remedy, however, carries with it significant personal and institutional disincentives for judges and courts that the Court has simply not accounted for in its analysis. ${ }^{321}$ And, as the reach and pervasiveness of pretrial publicity

313. Minow \& Cate, supra note 269, at 635 (tracking the rise of new technologies and the "explosion" in news coverage available to potential jurors).

314. Whellan, supra note 266 , at 176 .

315. Garcia, supra note 34, at 1110-11 (1992) (tracing the roots of the conflict between free press and an impartial jury back to Chief Justice Marshall and the trial of Aaron Burr).

316. Joanne Armstrong Brandwood, Note, You Say "Fair Trial" and I Say "Free Press": British and American Approaches to Protecting Defendants' Rights in High Profile Trials, 75 N.Y.U. L. REV. 1412, 143132 (2000) (noting English courts' concern over threat to fair and just proceedings presented by unfettered publicity, in contrast with American courts).

317. Reynolds v. United States, 98 U.S. 145, 155-56 (1878).

318. United States v. Burr, 25 F. Cas. 49, 50-51 (C.C.D. Va. 1807) (No. 14,692g) (noting that, to declare a juror objectionable, the trial court must determine whether the "prepossessions" a juror has rises to the level that causes the juror to "close the mind against the testimony that may be offered . . which will combat that testimony[] and resist its force").

319. Coleman v. Kemp, 778 F.2d 1487, 1540 (11th Cir. 1985) ("In Rideau . . . the Supreme Court specifically rejected the view that a habeas petitioner must establish a 'substantial nexus' between the pretrial publicity and the petitioner's trial. The reason for such a rule is clear: when the extremely high showing required by Rideau is made, prejudice is manifest and thus is presumed." (citation omitted) (citing Rideau, 373 U.S. 723, 729 (1963) (Clark, J., dissenting))).

320. See, e.g., Mu'Min v. Virginia, 500 U.S. 415, 428 (1991) (suggesting the presumption remains viable in cases involving a "wave of public passion" (quoting Irvin v. Dowd, 366 U.S. 717, 728 (1961)); Patton v. Yount, 467 U.S. 1025, 1035 (1984) ("In the circumstances of this case, we hold that it clearly rebuts any presumption of partiality or prejudice that existed at the time of the initial trial.").

321. But see Farmer, supra note 16, at 10 ("Perhaps the most-often-cited reason for denying motions for 
in high-profile cases grows, as has happened in the Internet age, these disincentives magnify because greater exposure of jurors to higher levels of (increasingly unfiltered) pretrial publicity would inescapably lead to more and more venue changes under the pretrial publicity standard as initially constructed. ${ }^{322}$

This Article tracks a pretrial publicity standard that has, for all practical purposes, morphed into a "courtroom decorum" standard, under the totality of the circumstances test. The problem with this transformation is that the interests protected by a court decorum standard are not the same as those protected by the original pretrial publicity standard. A courtroom decorum standard is a right to be tried in a solemn and dignified atmosphere, or at least not in a circus atmosphere. ${ }^{323}$ The pretrial publicity standard is a right to be tried by a jury that excludes individuals whose ability to base a verdict solely on the evidence at trial has been compromised by exposure to extraneous, untrue, or irrelevant information. ${ }^{324}$ The interests protected by a constitutional standard that hinges on the dignity of a trial proceeding are institutional ideals of the level of formality that should attend a judicial proceeding, not necessarily the due process interests of a criminal defendant. Although an undignified trial proceeding might not satisfy the law's normative construct of a proper criminal trial, a lack of formality in a proceeding may have little, if any, actual bearing on whether the defendant's jury was impartial. The reformulation of the pretrial publicity standard as one that primarily vindicates institutional norms and systemic interests comes at a cost - to the extent defendants, practitioners, and the public perceive the change of venue or any constitutional standard as a meaningless formality, confidence in the fairness of the legal system is undermined. This danger is peculiarly acute in the high-profile cases that are the fodder of change-of-venue motions because it is in those cases where the legal system's ability to ensure a trial that comports with the public's perceptions of fairness is on full display. ${ }^{325}$

The title of this Article poses the question - if Skilling can't get a change of venue under the federal pretrial publicity standard, who can? The answer, currently, is whoever can come forward with evidence of juror bias sufficient to convince an individual trial judge in the first instance to move his or her chambers for the duration

change of venue is the use of judicial resources, inconvenience of witnesses or parties, and, as an amicus characterizes it, general efficiency considerations."). See supra notes 263-69 and accompanying text for a discussion for how judicial proclivities and appearances could influence a change-of-venue decision.

322. While I agree that " $[\mathrm{t}]$ he Sixth Amendment's right to a fair trial should trump any and all docket, judicial-resource, convenience, or efficiency reasons," Farmer, supra note 16, at 10, the reality is that the standard currently allows those considerations to play a role in change-of-venue decisions.

323. See, e.g., Irvin v. Dowd, 366 U.S. 717, 728 (1961) (noting that a defendant has a right to be tried in an atmosphere undisturbed by public passion); Moore v. Dempsey, 261 U.S. 86, 96 (1923) (exemplifying the way in which trial observers can disturb the trial environment by pointing to "repeated instances" of verdicts set aside due to "disorder" in the courtroom).

324. See supra notes 125-27 and accompanying text for instances where the Court has overturned cases due to the jury being tainted by extraneous information.

325. See Carolyn Stewart Dyer \& Nancy R. Hauserman, Electronic Coverage of the Courts: Exceptions to Exposure, 75 GEO. L.J. 1633, 1635 n.12, 1647 n.54 (1987) (explaining the rules of various jurisidictions on electronic recording and newsgathering in courtrooms). 
of the trial proceedings. There is an obvious problem with a procedural safeguard for impaneling an impartial jury that leaves trial courts to apply their own individual criteria to the standard that triggers the safeguard. However, there are more concrete concerns with the contemporary prejudicial pretrial publicity jurisprudence. First, it has simultaneously failed entirely to resolve the constitutional dilemma posed by the modern phenomenon of mass dissemination of information about criminal trials. Next, it has overshadowed established implied jury bias principles recognized at common law by focusing exclusively on pretrial publicity in evaluating local juror bias.

The Court has recognized the doctrine of implied bias as a rule of constitutional procedure to ensure an accused's right to a fair and impartial criminal trial outside of the change-of-venue context. ${ }^{326}$ Derived from the common law principal challenge, implied bias exists where a potential juror's relationships or interests are such that the law will conclusively presume he or she cannot be impartial as matter of law without proof of actual bias. ${ }^{327}$ This proof of actual bias recognizes that "an inference of bias exists where a juror has a 'potential for substantial emotional involvement' that could 'adversely affect[] impartiality," or where a "juror is "connected to the litigation at issue in such a way that it is highly unlikely that he or she could act impartially during deliberations." 328 The implied bias inquiry is an "average person test"-if an average person in the same circumstances likely would be prejudiced, a juror will be deemed biased even if that juror is "objective in fact." 329 Contrary to the discretion afforded trial courts in conducting voir dire, "disqualification on the basis of implied bias is

326. For example, the law imputes bias to judges under circumstances where a judge's impartiality might fairly be questioned, even in the absence of evidence of actual bias. See, e.g., In re Murchison, 349 U.S. 133, 136 (1955) (explaining that fairness requires the "absence of bias" in trials and that "no man is permitted to try cases where he has an interest in the outcome"); Offutt v. United States, 348 U.S. 11, 14 (1954) (holding that a participating party's conduct "cannot fairly be considered apart from that of the trial judge," and that a new trial is warranted where a judge becomes "personally embroiled" with the petitioner).

327. See supra notes $21-28$ and accompanying text explaining that challenges at common law for disqualification of a juror were either "principal" or "to the favor," the former being upon grounds of absolute disqualification, the latter for actual bias.

328. William P. Barnette, Ma, Ma, Where's My Pa? On Your Jury, Ha, Ha, Ha!: A Constitutional Analysis of Implied Bias Challenges for Cause, 84 U. DET. MerCY L. REv. 451, 466 (2007); see also Ward v. Vill. of Monroeville, 409 U.S. 57, 59, 62 (1972) (reversing a conviction where the fact finder had perceived a financial interest in finding the defendant guilty); United States v. Polichemi, 219 F.3d 698, 704 (7th Cir. 2000) ("[A] court must excuse a juror for cause ... if the juror has even a tiny financial interest in the case."); United States v. Cerrato-Reyes, 176 F.3d 1253, 1251 (10th Cir. 1999) (implied bias can be found "when there are similarities between the juror's experiences and the facts at issue in the trial"); Burton v. Johnson, 948 F.2d 1150, 1159 (10th Cir. 1991) (finding that a juror who had been the victim of domestic abuse was impliedly biased in a case which turned on the battered spouse defense); United States v. Eubanks, 591 F.2d 513, 516-17 (9th Cir. 1979) (finding implied bias where in a heroin distribution trial where juror's two sons had been imprisoned as a result of heroin use); Jackson v. United States, 395 F.2d 615, 618 (D.C. Cir. 1968) (finding implied bias where a juror participated in a love triangle similar to one at issue in trial); United States ex rel. De Vita v. McCorkle, 248 F.2d 1, 8 (3d Cir. 1957) (finding that bias to be presumed on part of a juror who had been robbed in the context of an armed robbery case); United States v. Devery, 935 F. Supp. 393, 404 (S.D.N.Y. 1996) (finding implied bias where jurors had either been indirectly victimized by drug dealing, or were themselves involved in activity similar to that charged).

329. Barnette, supra note 328 , at 459 . 
mandatory." "330 Thus, if a prospective juror falls within a category of persons that law deems to be biased by implication, that juror must be excused as a matter of law. ${ }^{331} \mathrm{As}$ Chief Justice Marshall explained in Burr:

Why is it that the most distant relative of a party cannot serve upon his jury? Certainly the single circumstance of relationship, taken in itself, unconnected with its consequences, would furnish no objection. The real reason of the rule is, that the law suspects the relative of partiality; suspects his mind to be under a bias, which will prevent his fairly hearing and fairly deciding on the testimony which may be offered to him. . . . The relationship may be remote; the person may never have seen the party; he may declare that he feels no prejudice in the case; and yet the law cautiously incapacitates him from serving on the jury because it suspects prejudice, because in general persons in a similar situation would feel prejudice. ${ }^{332}$

The "mistrust of jurors who have a relationship with the victim," reflected in the common law implied bias doctrine, is not unique to the criminal justice system. ${ }^{333}$ In civil cases, mandatory exclusion of jurors with a pecuniary interest in the outcome of a case (either because they were harmed or because they will be affected by the verdict) is an unremarkable proposition, and that presumption of bias can extend to an entire community. ${ }^{334}$ For example, where a municipality is sued, the residents of that municipality will arguably have a personal interest in the outcome of the trial because a loss to the municipality may cause taxes to rise or services to be cut. ${ }^{335}$ Even though "the cost to each individual juror will be minimal, the cumulative effect of a trial before a jury, all of whose members will be adversely affected by a verdict[,] may be devastating." 336 The implied bias doctrine has been diminished over time in favor of an "emphasis on whether a litigant is able to prove actual bias on the part of a challenged juror, coupled with an increased deference to the trial judge's historically broad discretion in ruling on challenges for cause." 337 The contemporary phenomenon of large-scale litigation, such as large class action suits in the civil arena and criminal

\footnotetext{
330. $I d$.

331. Id.

332. United States v. Burr, 25 F. Cas. 49, 50 (C.C. Va. 1807).

333. Andrew Mayo, Note, "Non-Media" Jury Prejudice and Rule 21(a): Lessons from Enron, 30 ReV. Litig. 133, 152 (2010); see also Wash. Pub. Utils. Grp. v. United States Dist. Ct. for the W.D. of Wash., 843 F.2d 319, 327 (9th Cir. 1987) (explaining the court's duty to transfer a highly publicized case because many potential jurors in the pool would have a financial interest in the outcome); United States v. McVeigh, 918 F. Supp. 1467, 1474 (W.D. Okla. 1996) (moving the trial of the "Oklahoma City Bomber" to Colorado because of the profound effect the bombing had on the entire State of Oklahoma).

334. See, e.g., United States v. Polichemi, 219 F.3d 698, 704 (7th Cir. 2000) ("The concept of implied bias is well-established in the law. Many of the rules that require excusing a juror for cause are based on implied bias, rather than actual bias. For example, a court must excuse a juror for cause if the juror is related to one of the parties in the case, or if the juror has even a tiny financial interest in the case."); Wash. Pub. Utils. Grp., 843 F.2d at 327.

335. Wash. Pub. Utils. Grp., 843 F.2d at 327.

336. GoBerT ET AL., supra note 228, § 2:6, at 72-73 (citing Olson v. City of Sioux Falls, 262 N.W. 85

337. Barnette, supra note 328 , at 452 .
} (S.D. 1935)). 
prosecutions resulting from catastrophic events, calls for a renewed examination of this doctrine in evaluating questions of jury bias. ${ }^{338}$

In the types of cases that informed the pretrial publicity standard, it would be uncontroversial and indisputable that a victim of the crime or anyone connected to the victim would be automatically disqualified from juror service under the common law implied bias doctrine. Where a crime produces catastrophic harm in the charging venue, creating a large victim class who have suffered emotional, financial, or physical impact from the crime, or who are connected to someone who has suffered such harm, the local population itself will have a vested interest in the outcome of the case, and a similar presumption of bias should extend to the entire community. In the criminal trial change-of-venue context, application of this common law doctrine would give rise to a conclusive presumption of community bias in some high-profile modern cases. ${ }^{339}$ However, contemporary courts routinely reject defendants' jury bias arguments under the current pretrial publicity standard in cases involving terrorism targeted at a specific location, ${ }^{340}$ financial offenses with unique and widespread impacts in a community, ${ }^{341}$ or environmental crimes that cause significant injury in a particular geographical area. ${ }^{342}$ Crimes that cause or threaten catastrophic local harm, furthermore, are qualitatively different from the crimes involved in the cases that informed the pretrial publicity standard, crimes against a single or small number of victims. While exposure to information about a brutal murder may elicit revulsion towards the person accused of committing it, it is not the same as personal exposure to harm from a crime that threatened the entire community's well-being.

The proposition that high-impact crimes may have unique localized effects that require additional scrutiny of community bias is not new or radical - this is precisely the dynamic that led the trial court to change venue in United States v. McVeigh. ${ }^{343}$ And both the Fifth Circuit and the dissent in Skilling argued that widespread community harm should be a factor in courts' change-of-venue analysis under the

338. See id. at 453 (stating that the frequency of large-scale class actions and consolidated cases has increased the importance of examining the implied bias doctrine to ensure fair jury trials).

339. See Bennett L. Gershman, Contaminating the Verdict: The Problem of Juror Misconduct, 50 S.D. L. REV. 322, 346 (2005) (noting Scott Peterson's trial for killing wife and unborn child should have been moved due to community bias against Peterson).

340. E.g., United States v. Lindh, 212 F. Supp. 2d 541, 550-51 (E.D. Va. 2002) (refusing to grant a motion for change of venue in a domestic terrorism prosecution).

341. E.g., Skilling v. United States, 130 S. Ct. 2896, 2916-17 (2010).

342. See United States v. Grace, 408 F. Supp. 2d 998, 1021 (D. Mont. 2006) (refusing to change venue in a Clean Air Act trial despite the trial being held in the affected district), rev'd on other grounds, 504 F.3d 745 (9th Cir. 2007).

343. 918 F. Supp. 1467, 1470 (W.D. Okla. 1996) (finding that Oklahomans came to see the bombing as an event that affected not only those injured or killed, but Oklahoma City and the State of Oklahoma as a whole); see also Mayo, supra note 333, at 147 (arguing that widespread community harm should give rise to a conclusive presumption of local bias under Federal Rule of Criminal Procedure 21); Anemona Hartocollis, 10 Years and A Diagnosis Later, 9/11 Demons Haunt Thousands, N.Y. TIMES, August 9, 2011, at A1 ("No one can say exactly how many people were exposed to the [September 11] attack, and how many will eventually become physically or mentally sick.”). 
totality of the circumstances inquiry. ${ }^{344}$ The arguments forwarded, to date, however, have been framed either as a discretionary "should," under Federal Rule of Criminal Procedure 21, or proposal that trial courts consider such harm as an additional factor under the constitutional totality of the circumstances inquiry. ${ }^{345}$ This Article argues that this consideration should be a stand-alone constitutional "must" under the Sixth Amendment, not just one more normative factor under an already highly subjective multifactor test either under Rule 21 or the constitutional pretrial publicity standard. In short, a retethering constitutional change-of-venue analysis to established common law principles of juror bias that have been neglected in the Supreme Court's effort to resolve the constitutional conflict between the impartial jury right and free press guarantees.

\section{CONCLUSION}

The current pretrial publicity change-of-venue standard provides little more than an illusion of constitutional protection to the impartial jury rights of high-profile defendants. ${ }^{346}$ It mandates procedural safeguards for impaneling impartial juries in those cases, while leaving trial courts to apply their own individual criteria to the standard that triggers those safeguards unconstrained by any meaningful appellate review. ${ }^{347}$ This is constitutionally indefensible. With Skilling, it appears that the Supreme Court's effort to craft a pretrial publicity standard that could reconcile defendants' constitutional impartial jury rights with press freedoms in a mediasaturated society is over. ${ }^{348}$ The phenomenon of high-profile large-scale litigation, however, was never fully anticipated under the under the Court's standard, and these types of crimes require recognition of a presumption of community-wide bias in criminal cases involving widespread and catastrophic local harm to ensure that impartial jury rights recognized under the common law remain extant under the Sixth Amendment.

344. Skilling, 130 S. Ct. at 2947 (Sotomayor, J., concurring in part and dissenting in part); United States v. Skilling, 554 F.3d 529, 561 (5th Cir. 2009).

345. See supra notes 231-33 and accompanying text for a review of case law forming the totality of the circumstances test.

346. See supra Part III.D for an examination of the unpredictable and unreliable jurisprudence governing the pretrial publicity change-of-venue standard.

347. See supra Section IV for a discussion of the varying conditions used by judges when considering a change of venue.

348. Skilling, 130 S. Ct. at 2902-03. 
